\title{
'Est haec effera gens': landscapes of negotiation on the former island of Walcheren, the Netherlands
}

\author{
Letty ten Harkel \\ University of Oxford
}

\begin{abstract}
Biographical note: Letty ten Harkel (University of Oxford) specialises in the interdisciplinary study of early medieval identities in the southern North Sea region, drawing on historical, literary and archaeological sources.
\end{abstract}

'This is a fierce people': with these words, Thiofrid of Echternach described the local population of Walcheren in his twelfth-century Vita Willibrordi Metrica. ${ }^{1}$ Walcheren was an estuarine island measuring c. $220 \mathrm{~km}^{2}$ and located strategically in the mouth of the River Scheldt (fig. 1), the main riverine connection between Flanders and the North Sea. Thiofrid was the representative of an abbey that had significant landed interests on Walcheren, situated in present-day Luxembourg some $300 \mathrm{~km}$ further inland. He had travelled to the region in the later eleventh century to mediate in a dispute between the local population and some members of the Flemish nobility, who had been granted the island in 1012 by the Emperor Henry II. In the 1060s, however, the people of Walcheren had revolted, and Robert the Frisian, son of Count Baldwin V, had threatened to kill the entire population of Middelburg, then as now the most important settlement on the island. ${ }^{2}$ When, at a later stage, Thiofrid wrote his Vita Willibrordi, he described the Walcheren population as rough, courageous and war-like:

Non iura verens neque leges, | Non assueta iugo, non imperio, sine freno, | Cervicis durae, motabilis ut maris undae, | Ex quibus est circa spumantibus insula cincta. ${ }^{3}$

(They fear neither laws nor commands, | they are used to neither yoke nor authority, without bridle, | stubborn in nature, and as easily moved as the waves of the foaming sea $\mid$ that surround the island.)

This anecdote is one of the earliest surviving descriptions of the people of Walcheren, and provides an insight into the relationship between the local population and supralocal powers acting as intermediaries between the local population and the Frankish kings. Its depiction of the Walcheren population conforms to literary conventions that emphasise the rebellious or even barbaric nature of marginal peoples. At the same time, it reveals a glimpse of contemporary external perceptions of this remote (as seen from the perspective of Echternach) island, emphasising the challenges in negotiating the effective control of strategically important border zones.

This chapter adopts an interdisciplinary approach to investigate how various external powers (including different supralocal ecclesiastical powers and Scandinavian leaders as well as Frankish rulers at the highest political level, whose political interests were often deeply interwoven) sought to control the - strategically important yet physically marginal - early medieval island of Walcheren, a 'peripheral' region as defined in the Introduction. It uses the notion of 'negotiated landscapes' to allow for a source-critical approach in an attempt to explore new interpretations of the available evidence. Much of the known early medieval archaeology on the island is concentrated in the three circular fortifications or ringwalburgen, at Middelburg, Domburg and (Oost-)Souburg (here defined as the three main 'localities' on the island). In the absence of historical sources that can convincingly elucidate their function, traditional research focused on their common circular shape as an indication that they formed part of the same defensive 'system'. More recently, however, differences in terms of size and internal occupation have become increasingly apparent. In a previous article I have therefore explored the notion that they formed part of 'a landscape of

\footnotetext{
1 Thiofrid of Echternach, Vita Willibrordi Metrica, ed. by Rossberg, 1. 215 (p. 25).

${ }^{2}$ Henderikx, 'Ontstaan en ruimtelijke ontwikkeling van Middelburg', p. 245.

3 Thiofrid of Echternach, Vita Willibrordi Metrica, ed. by Rossberg, 1l. 215-18 (pp. 25-26). See also Henderikx, 'Ontstaan en ruimtelijke ontwikkeling van Middelburg', p. 245-47.
} 
negotiation whereby different competing factions engaged in fortification building in order to lay claim to land, people, and resources', but without paying due attention to the available documentary evidence. ${ }^{4}$ This chapter expands on this notion, drawing on all available evidence, to create a possible scenario for the interaction between locality and different supralocal and royal polities in this context. It is intended as a critique of dominant site-type approaches and argues that common morphology does not imply a common political context, although it might imply a common identity. Following a brief introduction to the region's political history, the archaeology of the ringwalburgen will be discussed in more detail. This will be followed by a consideration of the evidence for competing factions on Walcheren more broadly, before turning to a specific analysis of the ringwalburgen in this light. In conclusion, it is suggested that the ringwalburgen - undeniable expressions of power - played a key role in a contested landscape whereby different parties negotiated control over this marginal yet strategic location. Although it must be acknowledged that the evidence base is both fragmentary and problematic, and all conclusions are therefore at best preliminary, it is intended to foster debate on an international comparative scale, and its inclusion in the current volume is therefore of prime significance.

The use of the terms 'marginal' and 'strategic' deserves some clarification. Walcheren, situated in the borderlands of the Frankish world, occupied a marginal position as seen from the perspective of the inland power bases of the Carolingian and later Ottonian rulers. Walcheren was also marginal in terms of its landscape. During the early medieval period this coastal island, consisting of low-lying peat marshes where sand dunes provided the only significant natural contours, was entirely surrounded (and frequently threatened) by the sea. ${ }^{5}$ Movement across the island was dictated by the location of waterways, because tidal inversion ridges (the result of marine and riverine sedimentation) represented the only relatively dry and firm land - in addition to the dune edge - that was suitable for permanent human occupation. Yet Walcheren was also a region of strategic importance, the river Scheldt being an important transport route into the Frankish realm, and representing the political border between the Middle and West Frankish kingdoms following their division in AD 843. ${ }^{6}$ This combination of political marginality and strategic importance explains why the nature of imposed power was not uniform, but was multi-scalar and characterised by a complex and deeply intertwined set of relationships between the royal/imperial court, other secular magnates, and the Church, both secular and monastic (also see Theory chapter).

\section{W alcheren in the early medieval period: political context and historical sources}

The historical source material for Walcheren's political history is fragmentary, but nevertheless illustrates a complex dialogue between various magnates operating on a regional scale and centralised Frankish power, which was not unanimous either. According to the Lex Frisionum, the island had originally been part of (West-)Frisia, situated close to its southernmost border, the Sincfal or - in modern Dutch - Zwin, a waterway on the border between modern-day Belgium and the Netherlands. ${ }^{7}$ The Lex Frisionum is probably eighth-century in origin, by which time Walcheren was - at least nominally - under Frankish control. From the 830s Viking raids plagued the Scheldt region. The Frankish Annals report a raid on Walcheren in AD 837, when many of the island's inhabitants were killed. The dead included a certain Count Ekhard, a regional ruler whose exact identity and status are somewhat of a mystery, and the Viking Hemming, who was fighting on his side and had apparently converted to Christianity. ${ }^{8}$ In 841 , Lothar I granted Walcheren and other areas to the Viking Harald - a relative of the Hemming who had been killed - to create a political alliance against his father, the emperor Louis the Pious, thus giving Harald the status of bonded

\footnotetext{
${ }^{4}$ Ten Harkel, 'A Viking Age Landscape of Defence', p. 254.

${ }^{5}$ Bazelmans and others, Atlas van Nederland in bet Holoceen.

6 The importance of the Scheldt as a border feature dates back to the Roman period, when it functioned as the dividing line between the provinces of Gallia Belgica to the south and Germania Inferior to the north; Besuijen, 'Rodanum', p. 79.

7 Lex Frisionum, ed. by Eckhardt and Eckhardt, pp. 36, 46, 58, 94, 96. For a reference to customs 'apud occidentales Fresiones inter Flehi et Sincfalam' (amongst the West-Frisians between Vlie and Zwin), see p. 94.

${ }^{8}$ Henderikx, 'De vroegste geschiedenis', pp. 13-14; Henderikx, 'Ontstaan en ruimtelijke ontwikkeling van Middelburg', p. 243.
} 
official (also see the Theory chapter, this volume). ${ }^{9}$ It is not certain that this involved the entire island, as there is also evidence for a villa with the same name, which may represent a subdivision of the island with certain central-place functions (see below); nevertheless, the implication is that this was also an attempt on Lothar's part to gain more effective control - through Harald - over this location of key strategic importance. Unfortunately for Lothar, Harald died soon afterwards and some dispute between the Frankish court and his brother Rorik - with whom Harald had jointly held Dorestad - ensued. Rorik promptly fell into disgrace and reportedly proceeded to plunder the Frisian region until the Frankish rulers gave in and granted him Dorestad and 'other regions' again in 850; it is unclear if Walcheren was included in this. ${ }^{10}$

By this time it is clear that royal power in the coastal zone of the Low Countries was significantly weakened as the Carolingian dynasty went in decline as a result of internal power struggles, and there seems to have been a variety of political actors with vested interests in the island. Piecing together information from a number of fragmentary written sources, Peter Henderikx has argued that the abbeys of St Willibrord (Echternach) and St Bavo (Ghent) already possessed landholdings on Walcheren by this stage. ${ }^{11}$ The Gesta Episcoporum Virdunensium states that Lothar II granted Walcheren to Hatto (Bishop of Verdun from 847-70 and Abbot of Echternach from 856-64) at some point during his life, probably in an attempt to create an intermediary authority over the island that was more in line with the concerns of the Frankish court, but the degree of effective control remains uncertain. ${ }^{12}$

Not only monastic landholders, but also Viking leaders may have had a continuing hold on the Scheldt region, possibly including Walcheren. A couple of tantalising references survive from the eleventh-century Historia de Sancto Cuthberto and the twelfth-century Annales Lindisfarnensis to a group of Scaldingi, which may be interpreted as 'Scheldt-Vikings', who were involved in the attack on York in 867 under the leadership of Ubbo Dux Frisonum/Fresciorum ('Count of the Frisians'). In addition, there is a reference from the Annales Lindisfarnensis to Ubbo, Halfdan and Ingvar leading a combined army of Danes and Frisians on Sheppey in 855. ${ }^{13}$ Whilst the Anglo-Saxon Chronicle and the various Frankish Annals refer to on-going Viking raids in the Scheldt region and further inland during the $880 \mathrm{~s}$ and $890 \mathrm{~s}$, Walcheren itself is not mentioned. Although Henderikx has rightfully pointed out that this does not mean that Walcheren was spared, it is also possible that the island served as a base for raids further inland or across the North Sea. ${ }^{14}$ Finally, a reference in the eleventh-century De Moribus et Actis Primorum Normanniae Ducum by Dudo of St Quentin relates how the local inhabitants of Walcheren attacked the Viking leader Rollo, future first Duke of Normandy, during his stopover on Walcheren in the 870s. In response to these hostilities, Rollo laid waste to the region, which he supposedly did with the help of a few shiploads of warriors and supplies sent to him by a certain Anglo-Saxon King Alstemus. ${ }^{15}$ The conclusion to be drawn here is that, as ever, the political situation was clearly more complex than a straightforward conflict between 'Vikings' and 'natives': complex alliances existed between the various parties.

Only from the middle of the tenth century did the coastal regions return to some kind of centralised control under the Ottonian rulers. In the 970s, Otto II first bestowed (part of?) Walcheren on his wife Theophanu as a wedding gift, and a few years later confirmed certain possessions on the island to the Abbey of St Bavo (Ghent). ${ }^{16}$ Specific details of the interaction

${ }^{9}$ Henderikx, 'De ringwalburgen', p. 83

10 Ibid., pp. 83-84.

${ }^{11}$ Henderikx, 'Walcheren van de 6e tot de 12e eeuw', p. 121, n. 25; Henderikx, 'Ontstaan en ruimtelijke ontwikkeling van Middelburg', pp. 243-44.

${ }^{12}$ Henderikx, 'De ringwalburgen', pp. pp. 81, 87; Gesta Episcoporum Virdunensium, ed. by Waitz, p. 45.

13 Historia de Sancto Cuthberto, ed. by Arnold, p. 202; Annales Lindisfarnenses, ed. by Pertz, s.a. 868. Also see Henderikx, 'De ringwalburgen', pp. 87-88; IJssennagger, 'Between Frankish and Viking', p. 83.

${ }^{14}$ Henderikx, 'De ringwalburgen', pp. 88-94. Also see Braat, 'Zeeland in the Vikingtijd', pp. 140-42; Ten Harkel, 'A Viking Age Landscape of Defence', p. 251.

15 Alstemus is regarded as a contraction of the Old English name Athelstan. It has never been resolved whether the Athelstan mentioned here was the tenth-century Athelstan of Wessex (924-39), wrongly reassigned to the later ninth century, or King Guthrum of East Anglia (879-90), whose baptismal name was Athelstan. It has also been suggested that the king referred to here was in fact King Alfred of Wessex (87199), and the name Alstemus a misspelling. For an in-depth discussion, see Dudo of St Quentin, History of the Normans, ed. and trans. by Christiansen, p. 189, n. 137.

${ }^{16}$ Henderikx, 'De ringwalburgen', p. 81. 
between centralised Frankish power and more regionally rooted concerns, such as arrangements for taxation and tribute, are unknown. On a general level, consistent with some high medieval documentary evidence as well as faunal remains and evidence for textile manufacture from Souburg, it seems that the primary economic significance of Walcheren pertained to sheep husbandry. ${ }^{17}$

In addition to these tentative insights into Walcheren's political situation, there are a number of documentary and archaeological sources that can shed some light on other aspects of Walcheren's relationship with more inland regions of the Frankish realm and other surrounding territories. Alcuin's late eighth-century Vita Sancti Willibrordi recalls how the missionary Willibrord (c. 658-739) had arrived at 'quandam villam Walichrum nomine' (a villa called Walichrum ['the moist sand ridge']), and smashed 'antiqui erroris idolum' (an idol of the ancient superstition), angering the local pagan priest. ${ }^{18}$ This reveals that there had been some kind of central place dedicated to pagan worship on the island, existing in conflict with the missionary concerns of the Frankish rulers and Church. Archaeological evidence furthermore attests that there was an early medieval emporium with associated cemeteries on Walcheren, c. $1 \mathrm{~km}$ from the later ringwalburg of Domburg, overseeing the Oosterschelde, then the navigable arm of the Scheldt estuary. The existence of an emporium here, which has now been entirely destroyed by the sea, is attested by antiquarian observations and large quantities of beach finds - including three Islamic dirham fragments, one set into a decorative double beaded rim, indicative of connections with Scandinavia - that hint at prosperity levels comparable to the better-known emporium at Dorestad. ${ }^{19}$ The Domburg region also yielded much earlier archaeological remains (now also destroyed by the sea) of a middle Roman temple dedicated to Nehalennia, an originally indigenous goddess of fortune and protector of seafarers and merchants..$^{20}$ Given the persistent evidence for archaeological sites with central-place functions in the Domburg region, the villa called Walichrum from the Vita Sancti Willibrordi is often argued to have existed in this location also, which - if correct - might possibly represent evidence for a longlasting pre-Christian ritual centre in this vicinity. ${ }^{21}$ Whatever the precise location of the idol smashed by Willibrord, the eleventh-century Passio Friderici Episcopi Traiectensis reveals that the island's population still 'required' further missionary activity (at least in the eyes of Louis the Pious) during the office of Bishop Frederic (820-38), suggesting that Christianisation was not as thorough at this stage as the centralised Frankish powers preferred.22

Finally, there is a piece of skaldic poetry, supposedly composed in the later tenth century by Hallfreðr vandræðaskáld ('the troublesome skald') (c. 965-1007) but included in a thirteenth-century manuscript, which separately identifies the inhabitants of Walcheren as a distinct group amongst a list of 'peoples' killed and defeated by King Ólafr Tryggvason:

Tỉðhoggvit lét tyggi | Tryggva sonr fyr styggvan | Leiknar hest á lesti | ljótvaxinn hræ Saxa. | Vinhróðigr gaf víða | vísi margra Frísa | blǫkku brúnt at drekka | blóð kveldriðu stóði.

\footnotetext{
17 Henderikx, 'Walcheren van de 6e tot de 12e eeuw', p. 121, n. 25; Henderikx, 'Ontstaan en ruimtelijke ontwikkeling van Middelburg', pp. 243-44. Also see Deckers, 'Between Land and Sea', pp. 57-62.

${ }^{18}$ Latin text from Alcuin, Vita Sancti Willibrordi, ed. by Wattenbach and Dümmler, Book 1, ch. 14. Translation from Grieve, Willibrord, p. 112. For place-name evidence, see Künzel, Blok, and Verhoeff, Lexicon, pp. 381-82. ${ }_{19}$ Van Heeringen, 'Kolonisatie en bewoning in het mondingsgebied van de Schelde', p. 43; Henderikx, 'De ringwalburgen', p. 77; Hill, 'A Short Gazetteer of Postulated Continental Wics', pp. 105-06; Schoneveld, 'Historische Context', p. 34. For a recent reappraisal of the beach site, see Deckers, 'Between Land and Sea', pp. 295-381. Two of the dirhams were of ninth-century date; the third is now lost. Given the low quantity of dirbam finds in comparison with, for example, Hedeby in Denmark, and the fact that one of the two was adapted into a decorative piece, it is not suggested here that they represent evidence for trade connections with the Arab world. It is more likely that they ended up on Walcheren as the result of the movement of traders and other travellers through the southern North Sea waters.

20 Van Dierendonck, 'Romeinse tijd', pp. 51-54; Stuart and Bogaers, Nehalennia; Tuinman, 'Romeinse Nehalennia-altaren in Zeeland'.

${ }^{21}$ Lebecq, 'L'Emporium Proto-Médiéval de Walcheren-Domburg', pp. 296, 301; Besuijen, 'Rodanum', pp. 23-6.

${ }^{22}$ Odbert of St Bertin, Passio Friderici episcopi Traiectensis auctore Odberto, ed. by Holder-Egger, pp. 34749.

Deckers, 'Between Land and Sea', p. 302.
} 


\section{[...] | Rógs brá rekka lægir | ríkr Valkera líki; | herstefnir lét}

hrǫfnum | hold Flæmingja goldit. ${ }^{23}$

(The ruler, Tryggvi's son [=Óláfr Tryggvason], had the corpses of Saxons cut down often, finally, before the edgy, ugly-grown horse of Leikn <troll-woman. [WOLF]. Far and wide the friendexulting prince gave the black stud of the evening-rider [TROLLWOMAN > WOLF] the dark blood of many Frisians to drink.

The powerful subduer of the strife of men [JUST RULER] spoiled the bodies of the Valkerar; the army-commander [RULER] caused the flesh of the Flemings to be doled out to ravens.)

The degree to which skaldic verse preserves earlier oral traditions or should be seen as a reflection of thirteenth-century society remains a point of debate. Nevertheless, this passage reveals that at some point before the thirteenth century the 'Valkerar', the inhabitants of Walcheren, had entered common consciousness as an opponent worthy enough to be included in a praise poem celebrating the victories of Ólafr Tryggvason. As such, it conveys a similar sentiment to the twelfth-century Vita Willibrordi Metrica written by Thiofrid of Echternach. Although both were literary constructions written down at a time when Walcheren was to all accounts and purposes an integral part of the Frankish realm, they would have been ineffective as such unless rooted in some form of common perception, and it is not unthinkable that such external views on Walcheren's identity were grounded in an earlier reality.

\section{The archaeology of the ringwalburgen}

The various written sources presented above all represent external, supralocal perspectives, a far cry from the Dense Local Knowledge (DLK) discussed in Escalona's contribution to this volume. There is an obvious break in the period between the later ninth and the later tenth centuries, both in terms of surviving sources and textual references that refer to Walcheren. This is in itself not surprising, as localities are usually only described in medieval historical sources as the backdrop for royal or aristocratic power (see the Introduction to this volume). Yet the later ninth century is also the broad period that witnessed construction of the ringwalburgen of Domburg ('the dune fortress'), Middelburg ('the middle fortress') and Souburg ('the south fortress'), situated in the present-day village of Oost-Souburg. ${ }^{24}$ This dating is based on a combination of pottery assemblages (consisting predominantly of tenth-century Pingsdorf ware, as well as other (near-)contemporary pottery types such as Hunneschans, Kugeltopf and Badorf ware) and scientific (radiocarbon) dating of structural remains (mostly waterlogged timber), although the evidence is not fine-grained enough to know whether they were built at exactly the same time or at, for example, ten- or even twenty-year intervals. ${ }^{25}$ The traditional academic consensus, drawing a parallel with traditional views of the

${ }^{23}$ Hallfreðr vandræðaskáld, Óláfsdrápa, ed. and trans. by Whaley, st. 3, second half of 4. Old Norse text and English translation, including explanations of kennings, from Whaley, Poetry from the Kings' Sagas, 1, pp. 394-96. The inhabitants of Walcheren are the Valkerar, also see Henderikx, 'De ringwalburgen', p. 102.

${ }^{24}$ The names of the fortresses may seem suggest they were a coherent group, Middelburg being literally 'the middle fortress' in relation to the other two, but the earliest recorded instances date to the twelfth (Middelburg and Domburg) and fourteenth centuries ((Oost-)Souburg) respectively. These naming practices are therefore not representative of their 'identities' at the time of their construction and initial occupation. The suffix Oost- post-dates the construction of the ringwalburg as well, referring to the (modern) part of the village where it is currently located. In this chapter, I will use 'Souburg' to indicate the early medieval ringwalburg and 'Oost-Souburg' and 'West-Souburg' to indicate the two parts of the modern-day settlement.

${ }^{25}$ For the pottery, see Van Heeringen and Verhaeghe, 'Het aardewerk' (or see Ten Harkel, 'A Viking Age Landscape of Defence', pp. 230-31 for a brief summary in English). For a list of 21 radiocarbon dates, see Van Heeringen, 'De resultaten van het archeologisch onderzoek', p. 38, table 1. The radiocarbon dates broadly fall between the later ninth and the end of the tenth centuries, but some are a bit earlier, and further 
West-Saxon burghal 'system', was that they were refuges built for the local population in case of Viking attack, although it has also been suggested that they were impositions of inland power over coastal communities, or temporary Viking camps constructed at a time when centralised Frankish power was at its weakest and had lost its grip over the coastal territories. ${ }^{26}$ The first two explanations suppose the direct involvement of royal power, which would render the textual silence somewhat more surprising. The textual silence is therefore better explained as an indication that the region had slipped entirely from the control and consciousness of supralocal Frankish authorities. This demonstrates the relevance of a re-consideration of the island's history and archaeology in the context of the present volume. ${ }^{27}$

One of the key characteristics of the distribution of ringwalburgen is their close proximity: the surface area of Walcheren is only c. $220 \mathrm{~km}^{2}$, yet there are no less than three forts. The distance from Domburg to Middelburg is only about $12 \mathrm{~km}$, whilst that from Middelburg to Souburg is only around $4 \mathrm{~km}$. This begs the question, what were they for? In what follows, a brief summary of existing scholarship on the three ringwalburgen on Walcheren will be provided to provide some descriptive and interpretative context. ${ }^{28}$

Domburg was located in the island's northern dunes, at a distance of $c .1 .5 \mathrm{~km}$ from the reconstructed location of the emporium. It was constructed in the later ninth or early tenth century. It was long assumed that the ringwalburg superseded the emporium, but Pieterjan Deckers's recent reappraisal has drawn attention to the fact that the chronology of the two sites overlapped, although their functional relationship remains open to question. ${ }^{29}$ Middelburg and Souburg, both probably constructed in the later ninth century, were situated on the relatively high ground of creek ridges cutting across the island. ${ }^{30}$ The fortresses of Domburg and Middelburg are located underneath the present-day village of Domburg and the provincial capital of Middelburg respectively, where on-going developer-funded excavations keep revealing new material. ${ }^{31}$ Their developmental histories were nevertheless quite different: whilst Middelburg gradually grew into the region's capital, the defences of Domburg lost their function in the late tenth or eleventh century, as occupation traces of this date were found cutting into the bank. ${ }^{32}$ The fortress of Souburg was likewise deserted in the eleventh century and never re-occupied, allowing for large-scale excavations between 1969 and 1994 and the reconstruction of the earthworks in 1994 (Fig. 2). ${ }^{33}$

As Souburg remains the most extensively excavated of the Zeeland ringwalburgen, with some $48 \%$ of the internal area investigated, its evidence was long assumed to be representative of all ringforts in the area. ${ }^{34}$ Some differences between the sites were nevertheless acknowledged, including their different sizes, Souburg being by far the smallest with a rampart diameter of $144 \mathrm{~m}$, whilst Domburg is the largest at $265 \mathrm{~m}$. The diameter of the rampart at Middelburg measures c. 220

complications exist because of the calibration curve for this period (ibid., pp. 36-39).

${ }^{26}$ For the traditional interpretation, see Van Dierendonck, 'The Early Medieval Circular Fortresses', p. 252; Van Heeringen, 'The Construction of Frankish Circular Fortresses'; Henderikx, 'De ringwalburgen', pp. 94101, 110-11; Huizinga, 'Burg en kerspel in Walcheren'. For the argument that they were impositions of inland power, see Loveluck and Tys, 'Coastal Societies, Exchange and Identity'. For the exploration of different interpretative frameworks, see Ten Harkel, 'A Viking Age Landscape of Defence'. The notion that Walcheren might have seen Scandinavian settlement already at an earlier stage has been explored by Lebecq, Marchands et Navigateurs Frisons, pp. 142-44.

27 This is particularly timely given the fact that there has been a recent revival of academic interest in the region, which took the form of a specialist workshop in the Netherlands in the autumn of 2013, the proceedings of which will be published in Deckers and Ten Harkel, eds, The Early Medieval Archaeology.

${ }^{28}$ For a more detailed overview, see Ten Harkel, 'A Viking Age Landscape of Defence'.

${ }^{29}$ Deckers, 'Between Land and Sea', p. 381.

${ }^{30}$ Henderikx, 'De ringwalburgen', pp. 99-101; Loveluck and Tys, 'Coastal Societies, Exchange and Identity', p. 160; Van Heeringen, Henderikx, and Mars, eds, Vroeg-middeleeunse ringwalburgen.

31 Ufkes, Een archeologisch onderzoek; Ufkes, Een archeologische opgraving; Meijlink and Silkens, Middeleeunse bewoning bij de Duinburg; Meijlink, 'New reflections on the Walcheren ringfortresses'.

32 Deckers, 'Between Land and Sea', p. 386; Henderikx, 'Ontstaan en ruimtelijke ontwikkeling van Middelburg'; Van Heeringen, 'Archeologische kroniek 1993', pp. 233-34; Van Heeringen, 'De burgterreinen', p. 31.

${ }^{33}$ Van Heeringen, Henderikx, and Mars, eds, V roeg-middeleeuwse ringwalburgen.

${ }^{34}$ See Ten Harkel, 'A Viking Age Landscape of Defence' or Van Heeringen, 'The Construction of Frankish

Circular Fortresses' for concise summaries of the archaeology of the fortress of Souburg in English. 
$\mathrm{m}$. The ringwalburg at Domburg stands out for a different reason as well. A total of three skeletons two women and one child aged 3-4 - have been excavated underneath the ringwalburg. ${ }^{35}$ At least one of the women can be interpreted as a deliberate foundation burial. She was buried directly underneath the rampart, not too far from one of the postulated entrances into the ringwalburg, in a coffin of reused ship's timbers. Some of the rampart sods seem to have been deliberately stacked up against the coffin. ${ }^{36}$ The timber used for the coffin was dendrochronologically dated to $c .825$, which means that the burial (allowing for the absence of sap wood and the use-period of the ship) could be dated to the later ninth century, which is in accordance with other dating evidence for the construction of this ringwalburg. ${ }^{37}$

Recent developer-funded investigations have called into question further presumed similarities between the ringwalburgen. The internal area of Souburg was divided by a cross-shaped street pattern with wooden walkways and underlying drainage systems, and wooden bridges leading over the ditch. ${ }^{38}$ Three different post-built house types were identified, none of which was uncommon for the coastal zone of the Low Countries, creating the impression of a dense and somewhat organically grown internal occupation. ${ }^{39}$ It is not uncommon to see reconstructions of the internal lay-out of Souburg super-imposed onto location maps in grey literature reports detailing investigations in the other ringwalburgen, but it is increasingly clear that the density of occupation, the arrangement of property plots and the architectural techniques used in Middelburg and Domburg differed from those in Souburg. ${ }^{40}$

The artefactual evidence from Souburg is typical for a coastal North Sea settlement involved in trade and manufacture, tied in to the immediate hinterland as well as to regions further afield. The assemblage includes pottery from the Rhineland and the Meuse region as well as some possibly locally produced wares; tephrite querns and sandstone whetstones from the German Eiffel and quartz phyllite whetstones from Telemarken in Norway; a single fragment of a soapstone bowl of possible Swedish provenance; a small ferrous metalwork assemblage consisting of weaponry, boat hooks and horse gear and an even smaller assemblage of fairly unremarkable non-ferrous brooches. ${ }^{41}$ Those assemblages, especially the whetstones, seem comparable to the regional-scale trade of granite hand querns that Alfonso Vigil-Escalera discusses in his contribution to this volume. The relatively low-quality metalwork assemblage from Souburg, consisting mostly of a handful of ansate and disc-brooches, compares poorly to the higher-quality metalwork with mostly Frankish, but also some Scandinavian affinities found during just one recent excavation in Domburg. ${ }^{42}$ Evidence for manufacturing in Souburg was found in the shape of ironworking slag and wool processing. ${ }^{43}$ Red deer antler (a non-native species) was used for comb making, indicating import of raw materials from further inland, whilst possible connections with the British Isles and

35 They form the subject of an ongoing project, Investigating the Dead in Early Medieval Domburg, by the author, in collaboration with Robert van Dierendonck (Zeeland Foundation for Cultural Heritage), Pieterjan Deckers (Vrije Universiteit Brussel), Raphaël Panhuysen (ANTHRO.nl), Esther Jansma (Cultural Heritage Agency of The Netherlands; and University of Utrecht), Petra Doeve (BAAC.nl), Michael Dee (University of Oxford), and Petrus le Roux (University of Cape Town), and is funded by the Medieval Settlement Research Group, the Society for Medieval Archeology, the Viking Society for Northern Research, the Province Zeeland, and the Stichting Nederlands Museum voor Anthropologie en Praehistorie (Foundation Dutch Museum for Anthropology and Prehistory).

${ }^{36}$ Deckers, 'Between Land and Sea', p. 384.

37 Van Dierendonck, 'The Early Medieval Circular Fortresses', pp. 262-63; Van Heeringen, 'Archeologische kroniek 1992', p. 194; Van Heeringen, 'De burgterreinen', p. 31.

${ }^{38}$ Van Heeringen, 'De grondsporen', p. 123; Trimpe Burger, 'Oost-Souburg, Province of Zeeland', p. 362.

${ }^{39}$ Van Heeringen, 'De grondsporen', pp. 127-41.

40 Meijlink, 'New reflections on the Walcheren ringfortresses'.

${ }^{41}$ Van Heeringen, 'Glas en metaal', pp. 172-73; Van Heeringen and Verhaeghe, 'Het aardewerk'; Kars, 'De voorwerpen van natuursteen'. If anything, only the quantity of whetstones was unusual in that they were of relatively high quality and particularly numerous, possibly suggesting they were used on more than a domestic scale; ibid., p. 191.

42 Daleman and Koopstra, 'Metaal en Slakmateriaal'.

${ }^{43}$ Van Heeringen, 'Glas en metaal', p. 172. Evidence for textile production consists of antler spindle whorls, bone needles and pin-beaters as well as a number of bone 'tridents' used in wool-working that are fairly typical for the region; Lauwerier and Van Klaveren, 'Bewerkt bot', pp. 199-200, 206-12; for similar examples from Antwerp, see Veeckman, 'The Semi-Circular Fortified Medieval Settlement', p. 281, fig. 8. 
Denmark were evident from the comb typology. ${ }^{44}$ The faunal material, consisting largely of sheep/goat and some cattle, in connection with textile manufacturing tools reflected the importance of wool trade. ${ }^{45}$

Based on evidence for recuts and rebuilds of the ditches and ramparts of the ringwalburgen, it was originally suggested that they had two distinct use phases: an initial 'empty' phase during which they functioned as refuges for an otherwise dispersed and mobile population consisting mainly of shepherds and their flocks, and a secondary permanent occupation phase which saw the refurbishment of their defensive earthworks. ${ }^{46}$ This two-phase interpretation followed a model first suggested in 1935 by the Dutch historian Johan Huizinga, who regarded Souburg along with Domburg and Middelburg, Burgh on Schouwen and Oostburg in Zeeuws-Vlaanderen (both also located in the Dutch province of Zeeland), as well as Veurne in Flanders and Bergues-SaintWinnoc and Bourbourg in northern France, as a defensive chain of vlucbtburgen (refuges) for the local population, built by the Carolingian rulers to protect the coast against Viking attacks (fig. 1). Suggested dates for the construction of this 'chain' of sites have included the 830s, when according to the Frankish Annals Louis the Pious made arrangements for the defence of the coast against Viking attack (which proved unsuccessful due to the 'disobedience of the Frisians'), and the 890s, based on a reference to 'castella ibi recens facta' (fortifications recently built here) in the Miracles of St Bertin. ${ }^{47}$ As stated previously, the latter date is more consistent with scientific and artefactual dates retrieved from the ringwalburgen, and is therefore currently the most widely accepted date for their construction, although it is also possible, given the extremely vague nature of both references, that neither refers to the Zeeland forts.

The notion that a string of empty fortifications was built de novo to provide protection for people and livestock was suggested at a time when there was an almost-complete absence of evidence for occupation on Walcheren (other than some unstratified pottery) prior to the ninth century, with the only recognised evidence for activity below the late ninth-century layers of the ringwalburg of Souburg consisting of some plough marks. ${ }^{48}$ This caused a logical problem, in that it would not explain why three forts were built at relatively close distances if there were hardly any people to protect. Within the last decade, the notion of an initial 'empty' phase was initially questioned after excavations in Domburg revealed a house that was stratigraphically positioned between the first-phase rampart and a secondary rebuild. ${ }^{49}$ More recently still, developer-funded excavations in Domburg revealed evidence for anthropogenic layers, several metres thick, beneath the lowest excavated levels that were dendrochronologically dated to the later ninth century (AD 878-903), whilst similar evidence was uncovered in Middelburg. ${ }^{50}$ In both cases, restrictions imposed by the developer-funded nature of the investigations excluded the possibility to investigate these layers in more detail and it remains uncertain exactly what kind of activity they represent. Elsewhere on Walcheren, evidence for occupation predating the construction of the ringwalburgen is also emerging although it remains very scarce. ${ }^{51}$ This may be a result of intensive peat digging during the medieval period and natural causes such as coastal erosion, the deliberate levelling of

${ }^{44}$ Lauwerier and Van Klaveren, 'Bewerkt bot', pp. 196-97.

45 Minor species represented included pig, bone, dog, cat, chicken, goose, and whale, as well as some ice skates manufactured from horse bones; Lauwerier, 'Veeteelt in Oost-Souburg'; Lauwerier and Van Heeringen, 'Objects of Bone, Antler and Horn'; Lauwerier and Van Klaveren, 'Bewerkt bot'.

${ }^{46}$ Van Heeringen, 'De grondsporen', pp. 121-22; Van Heeringen, 'De burgterreinen', pp. 21, 30-32, 36.

${ }^{47}$ For the 830s, see Sawyer, Kings and Vikings, p. 82. For the 890s, see Werveke, 'De oudste burchten'; Miracula sancti Bertini Sithiensia: libellus miraculorum, ed. by Holder-Egger, ch. 6; Annales Bertiniani, ed. by Waitz, s.a. 837.

48 Van Heeringen, 'De grondsporen', p. 120.

${ }^{49}$ Van Dierendonck, 'The Early Medieval Circular Fortresses', pp. 263-64. For a more detailed discussion of this issue, see Deckers, 'Between Land and Sea', pp. 102-03.

50 Deckers, 'Between Land and Sea', p. 383; Ufkes, 'Sporen en structuren', pp. 72-73; Wullink, 'Fysische Geografie', pp. 31-32; Bernard Meijlink (Walcheren Archaeological Service) pers. comm.

51 These include a single farmstead of late 7th- to 8th-century date near Serooskerke, and two vliedbergen including an early medieval Flachsiedlung of 9th-century date underneath a later motte at Hoogelande on central/south Walcheren, and a small terp with a building of 10th-11th-century date from Buttinge on Walcheren. The original interpretation of the vliedbergen was as refuges for shepherds and their flocks, but they are now regarded as mottes originating as terp dwellings; Dijkstra and Zuidhoff, eds, Kansen op de kwelder, pp. 72-74; Deckers, 'Between Land and Sea', pp. 253-56. 
channel ridges and peat compaction and oxidation, although - as Henderikx states in a forthcoming article - there are notably more archaeological findspots and sites on the island that date to the eleventh century or later. ${ }^{52}$

The recognition of the anthropogenic material below the earliest excavated occupation layers in Domburg has resulted in a revival of support for a construction date in the 830s but, as Deckers has pointed out, there is evidence that these anthropogenic layers are situated stratigraphically below the rampart. ${ }^{53}$ In other words, rather than a defensive 'network' built on previously unoccupied ground, at least two of the ringforts may have originated as fortifications of previously existing population centres (depending, of course, on the interpretation of the underlying anthropogenic material), possibly - in the case of Domburg at least - not entirely dissimilar to the Danish emporium of Hedeby, which was fortified in the tenth century. This begs the question of who ordered the construction of the ringwalburgen. Fortification building was long seen as a royal prerogative, but - if a late ninth-century construction date can be accepted - Huizinga's 'chain' straddles the border between the West and Middle Frankish realms at a time when royal power was weakened. It has therefore been suggested instead that the defence of the coastal zone was organised on a regional level, the sites south of the Scheldt constructed under Count Baldwin II of Flanders, whilst the remaining Zeeland sites should be attributed to other rulers whose identities remain uncertain. ${ }^{54}$ Who were these 'other' rulers? Were they local magnates, or distant aristocrats seeking to impose power? With this question in mind, the remainder of this paper will return to the themes of locality and supralocal polity that stand central to this volume.

\section{Disputing the locality?}

At the start of this paper I suggested that the ringwalburgen should be seen as elements in a contested landscape over which different factions tried to negotiate control. This suggestion overtly moves away from still-dominant site-type approaches rooted in culture historical analyses that interpret common morphology as indicators or distinct ethnic, cultural or regional groups. ${ }^{55}$ There is plentiful evidence that the habit of constructing ringforts was neither culturally nor geographically defined but occurred in different political and chronological contexts. ${ }^{56}$ Evidence from the early medieval North Sea zone in itself is varied. For example, similarities between the Danish Trelleborg-type fortresses and the ringwalburgen have often been highlighted. Yet the Trelleborg-type fortresses are attributed to King Harald Bluetooth and are dated roughly a century later, to the later tenth century, so it is likely that the only connection between the Trelleborg-type forts and the ringwalburgen is that they drew on a common North Sea repertoire. The Zeeland ringwalburgen and the Trelleborg fortresses are not the only sites of their kind either: early medieval ringforts can be found along the entire continental side of the southern North Sea. These include Rijnsburg (contemporary with the Zeeland ringwalburgen but seemingly with a radial rather than a cross-shaped street pattern) and Den Burg (possibly a century older than the ringwalburgen on Walcheren, and probably constructed in the context of political struggles between Frankish and Frisian rulers), both in the Netherlands, and Borgumsberg and Tinnumburg on the islands Föhr and Sylt (Nordfriesland, Germany), the latter situated within $10 \mathrm{~km}$ from a first-century ringfort, the Archsumburg. ${ }^{57}$

Within this broad group of early medieval circular forts, different groupings can nevertheless be observed. Comparison with the Trelleborg-type forts is again significant. Although of varying size as well, like the Zeeland ringwalburgen, the internal areas of the Trelleborg-type forts are organised according to the same recurring systematic arrangement of houses, making a more convincing case for the suggestion that this group was conceived by a single mind. ${ }^{58}$ Comparative

\footnotetext{
52 Henderikx, 'Walcheren in de vroege middeleeuwen'.

53 Schoneveld, 'Historische Context', p. 35; Ufkes, 'Conclusie', p. 185; Deckers, 'Between Land and Sea', p. 386.

${ }^{54}$ Henderikx, 'De ringwalburgen', pp. 94, 98; Blok, 'De Franken in Nederland', pp. 130-31.

${ }^{55}$ For a useful recent discussion of the lingering influence of culture historical approaches in archaeology, see Olivier, The Dark Abyss of Time, p. 110.

${ }^{56}$ Dijkstra and De Ridder, 'Circular Fortresses', p. 215.

${ }^{57}$ Ibid.; Segschneider, 'Die Ringwälle auf den nordfriesischen Inseln'.

58 Cohen, Viking Fortresses of the Trelleborg Type; Dobat, 'Die südskandinavischen Burgen'; Roesdahl and Sindbæk, 'Introduction', p. 15, fig. 1.5; Roesdahl and Sindbæk, 'The Purpose of the Fortress', pp. 390-91. If
} 
evidence is entirely absent from the ringwalburgen, which - as stated previously - have differing and less formalised internal layouts. What is more, the Trelleborg-type forts are set out at much greater distances across a wide geographical zone in locations that allow for control of important communication routes and consolidation and protection of the extensive territory of the Danish kingdom. ${ }^{59}$ By contrast, the ringwalburgen on Walcheren are huddled closely together. Of the three, only Domburg is situated in a prime location to control the important trade and communication route between the North Sea and the prosperous Flanders region, but Middelburg was situated further inland in the centre of the island, its access to the navigable Oosterschelde - via the creek ridges that represented the most likely overland communication routes - blocked by Domburg. Souburg was located even further south, and although it was closer to the North Sea than Middelburg, it was even further away from the main trade route of the Oosterschelde. The poorer finds assemblage from Souburg, in comparison with Domburg, clearly testifies to this.

In summary, if site morphology does not necessarily equal political, chronological or ethnic context, and given the noted differences and closely spaced distribution of the Walcheren ringforts, the notion that they formed part of a single 'system' is no longer certain. Here, it may be worth taking a comparative look at different research regional and chronological research traditions focusing on dense clusters of earth-built fortifications. An interesting parallel from the early medieval period may be the relatively dense spread of (near-)contemporary tenth-century ringforts in the Elbe region. Joachim Henning has suggested that these practically indistinguishable constructions were built at the instigation of different magnates on both sides of the Frankish-Slavic frontier, explaining their similarities by reference to the fact that the frontier zone should be understood as a cultural buffer with a common material repertoire. ${ }^{60}$ Looking further back in time, a similar argument has been brought forward for the Iron Age hillforts in the landscape of the Cheviots (English/Scottish Borders). ${ }^{61}$ These also display significant commonalities in their construction method and generally short occupation span (possibly comparable to or even shorter than that of the ringwalburgen). Like the ringwalburgen, they are furthermore scattered across the landscape in close proximity to each other. Yet the prehistoric hillforts of the Cheviots are never interpreted as representing the imposition of a centralised authority, but rather as elements in a power dialogue in an otherwise fragmented society consisting of highly autonomous and fairly isolated groups. ${ }^{62}$

In what follows, I will explore the scenario that the ringwalburgen of Walcheren were key elements in a landscape of conflict and negotiation between various competing factions, each in competition with each other in an attempt to establish some kind of control over the locality. The question that presents itself is, again, who, then, built them? Candidates might include the monastic landholders mentioned previously, representing an intermediary authority that was legitimised by the Frankish royal court and - from the perspective of the locality - still very much a supralocal or external polity, albeit on a more localised scale than the Frankish kings. Henderikx has interpreted a reference from a twelfth-century document from Echternach that refers to the abbey's possessions in Middelburg infra vallum (literally 'underneath the wall/rampart') as being inside the defences of the ringwalburg, and has suggested the abbey may therefore have been involved in their construction. ${ }^{63}$ Middelburg's central and (relatively) landlocked location on Walcheren would certainly fit a scenario of (attempted) imposed centralised Frankish power over the island through delegating direct responsibility to a powerful landholder. Although Henderikx's suggestion

the Trelleborgs can nevertheless be seen as inspired by the Zeeland ringwalburgen, it is interesting to note that the choice of prototype was a type of architecture that existed in a marginal zone of the Carolingian realm, suggesting that Scandinavian peer polity interaction with the Carolingian realm during the period of Scandinavian state formation was selective in its territoriality, preferring an association with a liminal part of the realm.

${ }^{59}$ Roesdahl and others, eds, Aggersborg, pp. 383-409.

${ }^{60}$ Henning, 'Civilization versus barbarians?'.

61 It must be noted, however, that the West-Saxon burbs were probably not 'conceived as part of a single system' from the outset, but represent the outcome of a multi-phase defensive strategy; Baker and Brookes, eds, Beyond the Burghal Hidage, p. 66. Also see Hill and Rumble, The Defence of Wessex.

${ }^{62}$ Ferrell, 'Space and Society', p. 133; Oswald, 'An Iron Age Hillfort on Fawcet Shank: Survey Report', (Swindon: English Heritage, 2000), , p. 18.

${ }^{63}$ Henderikx, 'Ontstaan en ruimtelijke ontwikkeling van Middelburg', p. 244. 
necessarily remains speculative, if Middelburg's attribution to Echternach can be accepted, in the current argumentation this does not clarify the identity of those responsible for the construction of the other ringwalburgen on Walcheren.

It is worth drawing attention to the issue raised by Deckers, that the importance of monastic landowners during this period was almost certainly overstated as a result of their dominance in the surviving documentary record, and that the role of secular local and regional magnates is understated. ${ }^{64}$ It is therefore unlikely that the specific identities of the various actors or even the question whether they were Frisian, Frankish or Viking - will ever be determined with certainty, but this does not impede a more detailed consideration of the evidence for conflicts of interest of the various local and supralocal entities that may have had claims on Walcheren. A letter dated to 1192 mentions the Abbey of Echternach's loss of possessions on Walcheren at the time of the Scandinavian invasions, implying not only that the Abbey already had lands on Walcheren prior to the Viking raids, but also that some of these lands were estranged (for a time), presumably falling into the hands of the Vikings. ${ }^{65}$ Land did not only pass to the Viking invaders through direct military aggression, as evidenced by Lothar I granting (part of?) Walcheren to the Viking Harald. Neither was land granted exclusively to the Vikings, as can be deduced from the abovementioned monastic landholdings on Walcheren and the fact that, at one stage, Walcheren had a Count, the Ekhard who was killed in AD 837. This practice of giving out tracts of land to various stakeholders reflects the same strategy as that explored by Carvajal Castro (this volume), whereby the granting of spatial units is used to exercise elite control over local communities. ${ }^{66}$ That these strategies were not always successful is clear from Thiofrid's Vita Willibrordi, detailing local revolt against supralocal strategies to control the region, and also from the 'disobedience of the Frisians' that caused Louis the Pious's coastal defence strategy to fail in the 830s (see above).

The notion of local disobedience to supralocal and royal power compares interestingly to the relationship between Iceland and Norway discussed by Vésteinsson (this volume). Vésteinsson distinguishes between inclusive and exclusive territorialities, the former resulting in the absorbing of ideas from a larger zone because a locality already considers itself to be a part of this zone, and the latter in the definition of local identity in opposition to a larger region. Both can occur for a multitude of reasons, and neither are necessary mutually exclusive, but depend on scale and context. In the case of Iceland and Norway, as Vésteinsson (this volume) argues, the situation is characterised mostly by inclusive territoriality, but the 'disobedience' mentioned in the historical sources of the population of the coastal zone of the Low Countries - spatially much less far removed and more easily traversed from its political heartland - seems to represent an example of exclusive territoriality in relation to the Carolingian state and its representatives. Yet if there is evidence for exclusive territoriality where the relationship between the Walcheren population and the Frankish state apparatus is concerned, there is evidence for a more inclusive territoriality with a broader North Sea cultural identity from the archaeological evidence. As summarised above, this represents a mixture of cultural influences typical of the broad North Sea coastal zone, including evidence for links with the Frankish Rhineland, the local area and Scandinavia.

If there was local resistance against externally imposed Frankish inland power, there were supralocal attempts at a directed policy of Identitätspolitike (similar to that apparent in Anglo-Saxon sources such as the Anglo-Saxon Chronicle or Asser's Life of Alfred) to paint an image of a common Frankish - or Christian - 'people' locked in a struggle against a common enemy, arguably successful enough to result in our appreciation of the history of the period as being concerned almost exclusively with the struggles between 'Vikings' and 'natives', or 'pagans' and 'Christians, ${ }^{67}$ For example, the entry for 837 (the first recorded attack on Walcheren) from the Annals of St Bertin relates how 'Nordmanni [...] in insula quae Walacra dicitur nostros imparatos aggressi, multos trucidaverunt, plures depraedati sunt' (the Northmen [...] coming upon our people unprepared on

\footnotetext{
${ }^{64}$ Deckers, 'Between Land and Sea', p. 134.

${ }^{65}$ Henderikx, 'Walcheren van de 6e tot de 12e eeuw', p. 121, n. 25.

66 Annales Bertiniani, ed. by Waitz, s.a. 841. Annals of St Bertin, trans. by Nelson. The Annals do not attribute a label to the territory of Walcheren, but Alcuin's Vita Willibrordi refers to 'quandam villam [my emphasis] Walichrum nomine' (a villa called Walichrum) (see above). Given the size of the entire island, it is more likely that this was a subdivision, presumably with central-place functions, which shared the same name. As stated previously, it is not unthinkable that such a central place was located in the Domburg area.

${ }^{67}$ Pohl, 'Staat und Herrschaft', p. 32; Asser, Life of Alfred, ed. and trans. by Keynes and Lapidge.
} 
an island called Walcheren, they slaughtered many of them and plundered even more [my emphasis]). ${ }^{68}$ The annalist did not approve of Lothar's strategy to grant Walcheren and other territories to a Viking ruler either, as he was a heathen against which Christians should unite:

Dignum sane omni detestatione facinus, ut qui mala christianis intulerant idem christianorum terris et populis Christique ecclesiis praeferrentur, ut persecutores fidei christianae domini christianorum existerent, et demonum cultoribus christiani populi deservirent! ${ }^{69}$

(This was surely an utterly detestable crime, that those who had brought evil on Christians should be given power over the lands and people of Christians, and over the very churches of Christ; that the persecutors of the Christian faith should be sent up as lords over Christians, and Christian folk have to serve men who worshipped demons.)

The decision by Lothar to grant Walcheren and other coastal regions to a Viking leader regardless of such criticism may be explained by reference to the liminal nature of these territories, at least as seen from the political heartland of the Carolingian realm. ${ }^{70}$ Yet liminality is a subjective concept, and to regard Walcheren merely as marginal, based on its coastal location and distance from the Carolingian political core zone, is too simplistic. ${ }^{71}$ It was also economically important, as indicated by the evidence for the Domburg emporium, and occupied a key strategic location between the Carolingian realm and the outside world - the 'real' periphery - and the granting of some relatively important but troublesome territory to an equally troublesome opponent, thereby tying him into existing power structures, can be seen as a deliberate strategy to retain or increase control over this locality rather than allowing it to slip out of control. ${ }^{2}$

The implications of the decision to grant Walcheren to a Viking ruler deserve further comment. The notion that a Northman could be an acceptable ruler for a Frisian territory - coming from the same broad North Sea coastal zone - finds resonance in a passage from the Annals of Fulda, which describes how the local Frisian population of the area near Dokkum (Friesland, the Netherlands) managed to defeat a band of Vikings. The leader of the Frisians was 'unus Nordmannus, qui christianus effectus longo tempore cum eisdem Frisionibus conversatus est et eiusdem certaminis dux erat' (a Northman who had become a Christian and had long lived among these Frisians and was the leader of their attack). ${ }^{73}$ Although the Fulda annalist felt the need to draw attention to the aspects of this individual's character that made his role as leader acceptable from his own, supralocal perspective (he was a Christian and he had lived amongst the Frisians for a long time), it does not necessarily follow that similar concerns affected the local population. Then again, it might. Although on one level the Vikings belonged to the same coastal territories as the Frisians, they were also foreigners who spoke a different language and had a reputation for military aggression. By granting a territory to a Viking ruler, the Frankish rulers may therefore have caused a local response resulting in increased investment in the consolidation of power - for example through investment in fortress building - by the other parties who had vested interests in the island,

\footnotetext{
68 Annales Bertiniani, ed. by Waitz, s.a. 837. Annals of St Bertin, trans. by Nelson, p. 37. Although the translation provided by Nelson is given in the text, it must be stated that nostros simply means 'ours'; the translation adds 'people' but it is also possible that the inclusive identity referred to was a religious rather than an ethnic one. This would certainly fit better with the next passage that is quoted. Also, the expression in insula quae Walacra dicitur' could also be translated as 'in the island called Walcheren', which - together with the inclusive 'nostros' - would serve to emphasive an inclusive superimposed identity more effectively.

${ }^{69}$ Annales Bertiniani, ed. by Waitz, s.a. 841. Annals of St Bertin, trans. by Nelson, p. 51.

${ }^{70}$ In this sense the Frankish realm is very different from the Norwegian kingdom, discussed by Iversen (this volume), where the coastal zone was the geographical starting point for the rise of supra-regional power.

${ }^{71}$ Pohl, 'Conclusion: the transformation of frontiers', p. 259.

72 IJssennagger, 'Between Frankish and Viking'.

73 Annales Fuldenses, ed. and trans. by Rau, s.a. 873.
} 
whether they were monastic landholders or more localised rulers whose existence has completely escaped the written record.

Although much of what precedes is necessarily speculative, given the fragmentary nature of the evidence, the image that emerges is one of considerable complexity of various local and supralocal interests, their untangling complicated by the fact that the surviving historical material is entirely written from a supralocal perspective. The next section will readdress the significance of the ringwalburgen in this context, as expressions of conflict and interaction between different groups. This will be achieved through consideration of both spatial and temporal aspects, particularly their morphology and their differential developmental histories.

\section{Early medieval identities on $W$ alcheren}

There is an important distinction to be made between identifying the specific actors responsible for the construction of individual ringforts, and understanding the identity that the construction of a ringfort (or, indeed, any other such grandiose deed) conveyed. Identities are multi-layered and dynamic but also as essentially performative: people engaged in actions to signal their belonging (or distance) from a given group. ${ }^{74}$ It is therefore possible to say at once that each of the ringwalburgen on Walcheren was constructed by a different actor or even political opponent, but nevertheless conveyed the same broad identity. On one level - as with all undertakings that required the organisation of significant manpower and resources - this identity was that of a ruler or a leader, expressing status and power, providing protection and controlling resources. There are some other inferences that can also be made from a closer look at the fabric of the ringwalburgen.

It was stated earlier in this chapter that traditional interpretations of the ringwalburgen, which viewed them as a defensive 'system', frequently drew parallels with the West Saxon burghal 'system'. One aspect of all the ringwalburgen that sets them apart from the West-Saxon burbs, however, is their plan form. Some of the burbs were refurbished Roman towns, and others were de novo constructions, but these were often also modelled on the shape of Roman fortresses, thus appealing to an overall notion of Romanitas, an attempt at revival of that great state that had previously incorporated the Anglo-Saxon territories (see Theory chapter, this volume). ${ }^{75}$ This tradition of building or refurbishing burbs in the 'Roman' fashion in Anglo-Saxon England had a long chronology, and can be dated broadly between the 850 s and the 1000 s. ${ }^{76}$

Walcheren is also situated within the Roman limes, and typical rectangular Roman forts are known at nearby Aardenburg in Dutch Zeeuws Vlaanderen and Oudenburg in the coastal plain of Flanders. ${ }^{77}$ The Carolingian rulers are also known for their emulation of the Roman past, yet although there is evidence that Oudenburg was occupied during the ninth and tenth centuries, some have suggested it was used as a cattle enclosure during this period, and its masonry was robbed and reused for the contemporary castle at Bruges and possibly other settlements in the region. ${ }^{78}$ Whilst Aardenburg may have been re-occupied between the seventh and tenth centuries, evidence for occupation is scant, and it is unclear whether it had a strategic capacity; what is more, a

\footnotetext{
74 See Burke and Stets, 'Identity Theory and Social Identity Theory', for a useful discussion of identity as a performative act - a set of cognitive associations with multiple social categories - from the discipline of psychology.

75 Carver, 'What were they thinking?', pp. 932-33. However, John Blair, in the 2013 Ford lectures at the University of Oxford, which were based on research carried out in the context of the Leverhulme-funded project 'People and Places in the Anglo-Saxon Landscape', has recently suggested that alternative 'prototypes' may exist in the shape of (also rectangular) Iron Age forts, suggesting that 'the "burghal habit" in England began with re-using Iron Age hillforts, and only then extended to building new ones' (Blair, 'The British Culture of Anglo-Saxon England', pp. 33-34), a point that is also argued in slightly different form by Baker and Brookes, who regard the refortification of Iron Age hillforts and Roman towns as a first step in the WestSaxon defensive strategy, predating the construction of de novo strongholds (Baker and Brookes, eds, Beyond the Burghal Hidage, pp. 34-135). Blair's ideas will be published as The Foundations of Anglo-Saxon Society (forthcoming).

76 Baker and Brookes, eds, Beyond the Burghal Hidage, pp. 71-2.

77 The most recent publication on Aardenburg is Van Dierendonck and Vos, De Romeinse agglomeratie Aardenburg.

${ }^{78}$ Deckers, 'Between Land and Sea', p. 100; Henderikx, 'De ringwalburgen', p. 101; Ten Harkel, 'A Viking Age Landscape of Defence', p. 241.
} 
circular fortress may have been built at no more than $8 \mathrm{~km}$ distance, at Oostburg. ${ }^{79}$ Further north, the circular fort at Rijnsburg was built in close proximity to the Roman castellae known as the Brittenburg at Katwijk and Valkenburg. ${ }^{80}$

If the Roman era did not provide a prototype for the round shape of the ringwalburgen, the preceding prehistoric period is barely more informative. There are no known prehistoric forts in the southern coastal region of the Netherlands, and although some fortified enclosures of later Iron Age date are known from the eastern province of Drenthe, at Rhee, Vries and Zeijen, their planforms are (sub-)rectangular rather than circular. ${ }^{81}$ More convincing parallels for the ringwalburgen can be found in the ringforts of Scandinavia, not the aforementioned Trelleborg-type forts, which postdated the construction of the rinwalburgen, but a tradition that belongs broadly to the first millennium AD and the pre-Roman Iron Age. ${ }^{82}$

Of course there is a very practical element also to the decision to construct a circular fort, as circular earthwork enclosures are easier to construct and more durable than rectangular ones, which have their greatest weaknesses at the corners. Yet the ringwalburg of Souburg seems to have been perfectly circular, laid out with a precision that suggests its circularity was significant beyond merely being practical (Domburg and Middelburg have probably not been excavated extensively enough to know for certain that they were also perfect circles, althugh the evidence certainly does not exclude the possibility). In an analysis of the ringforts from the Scandinavian Öland region, which were characterised by three or nine entrances, Anders Andrén argues that these were symbolic constructions. Andrén also argues that - despite their different plan forms - these Scandinavian forts were influenced by Roman forts, as these, too, reflected ideas about respective cosmologies and world-views, and that the Scandinavian world view would have been more overtly expressed in the face of the expanding Roman world. ${ }^{83}$ It is possible that the emergence of fortifications on Walcheren, expressing a North Sea identity or world-view, should be understood similarly, in relationship to the expanding Frankish world-view, which seems to have become increasingly dominant even as the political stability of its centralised rulers underwent significant fluctuations. This does not, in any way, preclude the possibility that representatives of the Frankish state - either the Church or secular landholders - were involved in their construction, but rather that they may have worked in collaboration with local communities, or at least in acknowledgement of localised concerns.

If the general trend to erect circular fortifications can be taken to reflect a common North Sea identity, there are also some specific indications that provide possible insights into the identities of the factions responsible for the construction of - or seeking control of - individual ringwalburgen. The earthworks of Domburg, for example, contain a clue in the shape of the unfurnished female foundation burial in its coffin of reused ship-wood underneath the rampart. As argued previously,

\footnotetext{
${ }^{79}$ Besuijen, 'Rodanum', p. 49, fig. 14 for a simple plan of the Roman fortress at Aardenburg, situated in the present-day Dutch region of Zeeuws-Vlaanderen. Recent work by Van Dierendonck and Vos, published in , De Romeinse agglomeratie Aardenburg, has demonstrated, however, that the development of the fortress during the Roman and pre-Roman periods was significantly more complex than depicted by Besuijen, but this is beyond the scope of the current chapter. Also see Van Dierendonck, 'The Early Medieval Circular Fortresses', pp. 252, 266-67; Henderikx, 'De ringwalburgen', p. 77; Trimpe Burger, 'Aardenburg', p. 344; Deckers, 'Between Land and Sea'pp. 100-01.

${ }^{80}$ For a reconstruction of the layout of the fortress at Oudenburg, see Besuijen, 'Rodanum', p. 60, fig. 19. Also see Verhulst, The Rise of Cities in North-West Europe, pp. 17, 191; Ten Harkel, 'A Viking Age Landscape of Defence', p. 243; Dijkstra, Rondom de mondingen van Rijn en Maas, p. 115, fig. 4.2. It is not unlikely that the Brittenburg had at this stage already disappeared into the sea, but Valkenburg was located further inland, and early medieval settlement has been recognised in the vicinity.

81 See Roymans, Tribal Societies in Northern Gaul, p. 192, fig. 8.12 for a distribution map of fortified sites from the middle and late La Tène period in Belgium, northern France, the southern Netherlands and adjacent German regions. The only known 'defended' prehistoric site in the southern and central Netherlands is Voerendaal in the south-east of the country, in the modern province of Limburg; Schinkel, 'Hamlets on the Move': pp. 519, 537-38. Also see Van Heeringen, 'On Unsteady Ground', p. 593, on the lack of evidence for social hierarchies from settlement forms in the coastal zone of the Netherlands. For the Drenthe-sites, see Harsema, 'Farms Amongst Celtic Fields', pp. 550-51; Waterbolk, 'Walled Enclosures of the Iron Age'.

82 Andrén, Tracing Old Norse Cosmology, pp. 84-85. Also see Fallgren, 'The Ölandic Ring-Forts'.

${ }^{83}$ For example, Ismantorp had nine entrances, and Eketorp three. The Ölandic fortresses were on the whole smaller. Andrén, Tracing Old Norse Cosmology, pp. 105-12; Fallgren, 'The Ölandic Ring-Forts', pp. $29,42$.
} 
the area around Domburg with its emporium and earlier Roman temple complex was probably the island's oldest central place. It is not unlikely that this was the location of the villa Walichrum and the pagan centre of worship mentioned in the Vita Sancti Willibrordi, and of the earliest ninth-century church on Walcheren, possibly built as the result of Willibrord's missionary activities, mentioned in the eleventh-century Passio Friderici Episcopi Traiectensis. ${ }^{84}$ These may well have been contemporary; as stated previously, the same source also reveals that the island's population reportedly still required missionary activity in the ninth century, illustrating the obvious point that the establishment of a church does not immediately eradicate pre-Christian ritual practices.

Parallels for the placement of human inhumations in liminal locations in early medieval settlement contexts are not uncommon, although they would be highly unusual in a 'mainstream' Frankish Christian context, where churchyard inhumation burial was the norm. In the British Isles, they have their origins in pre-Christian traditions, although examples from the Christian era also exist. ${ }^{85}$ From the written record, they mainly seem to have non-Christian connotations. Neil Price has drawn attention to female burials in liminal positions described in the Poetic Edda, including two sorceresses buried near the entrances to different regions of the underworld ${ }^{86}$ Also relevant in this context is the burial of an actual woman interpreted as a female sorceress or volva ('wise woman') from the cemetery associated with the Trelleborg fortress of Fyrkat in Denmark (grave 4), although this is not from a boundary feature. ${ }^{87}$

Whether the woman buried underneath the Domburg rampart was a Christian or not will be impossible to establish and is entirely irrelevant, but construction of the rampart over the deliberately placed coffin would have been a significant ritual performed as part of the fortress building works. The practice of burying the dead in liminal settlement features has been linked to a strengthening of land claims through the ancestors (also see Martín Viso, this volume). ${ }^{88}$ This suggestion would fit well with the notion that the ringwalburgen represented key elements in a contested landscape, whereby different independent factions tried to lay claim to land, people and resources. It is possible, then, that this foundation burial represents a claim to power by a faction centring on the island's oldest central place region, possibly intended to signal independence from more mainstream Frankish cultural practices at the same time.

A final point that can provide further insights into the relationship between the various supralocal polities with vested interests in the island is the history of church foundation on Walcheren. Although Christianity almost certainly had an established presence on the island by the ninth century through missionary activities and the interests of monastic landholders such as Echternach, the parochial mother church of the island, the Westmonster, dedicated to St Martin, was probably not founded until the tenth century. Around this time, Middelburg was gradually taking over the role of central place at the expense of Domburg, which is emphasised by the fact that the Westmonster was constructed immediately outside the ringwalburg of Middelburg, rather than at Domburg. ${ }^{89}$

Henderikx has convincingly suggested that the Westmonster was a royal foundation..$^{90}$ It is unclear whether the foundation of the Westmonster at Middelburg was deliberately intended to curtail Domburg's pre-eminence or whether Domburg's role as the island's central place had already been taken over by Middelburg at a slightly earlier stage. In either case, the foundation of

\footnotetext{
84 Odbert of St Bertin, Passio Friderici episcopi Traiectensis auctore Odberto, ed. by Holder-Egger, pp. 347-49; discussed in Henderikx, 'Walcheren van de 6e tot de 12e eeuw', p. 149.

85 Sofield, 'Living with the Dead'; Hamerow, Rural Settlements and Society, pp. 106-7; Harrison, 'Beyond longphuirt?'.

86 Baldrs Draumar (Baldr's Dreams), preserved in a fourteenth-century manuscript, talks about the burial of a volva ('wise woman') at the east door (or east of the door) to Hel (Baldrs Draumar, ed. and trans. by Dronke, fourth stanza), and Grógaldr (Gróa's Spell) relates how a son invokes his dead mother from the gates of death to obtain her advice (Grógaldr, ed. by Bergmann, trans. by Bergmann, first stanza); Price, The Viking Way, pp. 113, 185-86.

87 Roesdahl, Fyrkat, vol. 2, pp. 83-104, 150 (p. 192 for English summary); Dobat, 'Die südskandinavischen Burgen', p. 62.

88 See for example Sofield, 'Living with the Dead'.

${ }^{89}$ Henderikx, 'Ontstaan en ruimtelijke ontwikkeling van Middelburg', pp. 245-46, 252; Henderikx, 'Graaf en stad in Holland en Zeeland', p. 56.
} 
the Westmonster directly outside Middelburg clearly signals direct royal meddling in the island's existing power hierarchy, declaring Middelburg as the centre of the island with direct links to the Frankish court, a point that would have been driven home even more clearly by the hustle and bustle of the actual building works taking place in the shadow of the ringfort. The appropriation of a pre-existing local power centre by a supralocal polity reflects the axiom that imposed supralocal power has a greater chance of success if embedded within and accepted by the locality, and is not entirely dissimilar to Davies's arguments (this volume) about scribal practices in Iberia.

The royal foundation of a parish church in association with the Middelburg fortress may have had political significance on a different level as well. The tenth century was a period of power consolidation by the revitalised Frankish court under the Ottonian rulers. During this period, the Ottonian rulers actively tried to re-establish centralised control over their coastal territories, which had fallen largely in the hands of local magnates and monastic landholders. If Henderikx (see above) is correct that the Abbey of Echternach had links to Middelburg, this would suggest that the Ottonian rulers directed this statement of royal power at the monastic elite. The choice of dedication (St Martin) in comparison to Echternach's patron saint St Willibrord is in that case telling. As discussed above, Willibrord's Vita recalls how the saint destroyed pagan idols on the island of Walcheren. The topos of smashing idols is also strongly associated with the fourth-century St Martin of Tours, an older saint with a more exalted status. ${ }^{91}$ The message that this dedication to St Martin expressed, therefore, was one of superiority and precedence. It is important to realise as well that the consecration of the church building, especially as it was a royal foundation, would have been another performative ritual carried out with due aplomb.

The internal conflicts between the supralocal polities who sought to control Walcheren did not end here. By the eleventh century, the Westmonster had become an eigenkerk (a proprietary church) of the Bishop of Utrecht, the result of the increased dependence of the Frankish rulers on the secular clergy during the tenth and eleventh centuries, and a symptom of the tensions between secular and monastic clergies that were played out at this time. ${ }^{92}$ Around 1100, Walcheren acquired its second church, founded as a daughter parish of the Westmonster: the Noordmonster, dedicated to none lesser than St Peter, also located immediately outside the ringwalburg of Middelburg on the opposite side. ${ }^{93}$ In her discussion of a letter written by Abbo, Abbot of Fleury, towards the end of the tenth century, Susan Wood has suggested that an important part of the monastic grievances towards the bishops at the time focused on the encroachment of the secular Church upon their lands, and the history of church foundation in Middelburg in this period suggests that these tensions were also felt on Walcheren. ${ }^{94}$

By the time Walcheren's three remaining pre-twelfth-century parish churches were established, at some point in the eleventh century, both Souburg and Domburg had been largely abandoned. From this moment, they can no longer be described as 'localities', reinforcing the point about endurance made in this volume's Theory chapter, although it was possibly not the absence, but the imposition of strong administrative systems that caused the changes. Their abandonment was traditionally taken to suggest that the first two ringwalburgen were no longer needed after the Viking raids had come to an end, but - as this paper argues - it is also possible that the varying fates of the three ringwalburgen reflect the outcome of ongoing power negotiations between different factions with interests on the island, with Middelburg emerging as the undisputed winner. The treatment of the abandoned earthworks of Souburg and Domburg may provide supporting arguments for this notion. If the appropriation of earthworks or monuments of older periods exemplified by their reoccupation or the construction of churches in close spatial association (also see Vigil-Escalera Guirado (this volume)) - suggests an explicit association with values attached to

\footnotetext{
${ }^{91}$ Although St Martin usually persuades the heathens he encounters with the power of his words to smash the idols of their own accord (Sulpicius Severus, Vita Sancti Martini, ed. by Fontaine, XV, 4), there are instances as well where the saint is aided by divine intervention (Sulpicius Severus, Dialogi, ed. by Migne, III: VIII and IX), most notably when he was miraculously saved from being crushed under a sacred pine, which the heathens deliberately cut down so it would fall on him (Vita Sancti Martini, ed. by Fontaine, XIII); Stancliffe, St. Martin and his Hagiographer, pp. 156, 328-40, 359-62.

92 Henderikx, 'Ontstaan en ruimtelijke ontwikkeling van Middelburg', pp. 245-46; Wood, Proprietary Church, pp. 812-24.

${ }_{93}$ Henderikx, 'Walcheren van de 6e tot de 12e eeuw', pp. 139-41.

94 Wood, Proprietary Church, p. 822.
} 
these earlier monuments, the deliberate avoidance of such monuments and/or their relegation to liminal locations in the landscape through the redrawing of boundaries reveals a distancing from these values. ${ }^{95}$ In this context it is perhaps noteworthy that the ringwalburg of Souburg never acquired an early church, but one of Walcheren's other pre-twelfth-century parish churches, dedicated to St Martin and therefore believed to be a daughter foundation of the Westmonster, was established in a new settlement zone in what is now West-Souburg, at about $1 \mathrm{~km}$ from the terrain of the ringwalburg. ${ }^{96}$ The evidence from Domburg is more telling still, as the parish boundary between the parishes of Oostkapelle and Westkapelle - both founded in the eleventh century and dedicated to St Willibrord - ran straight through the middle of the former ringwalburg of Domburg, thus marginalising the island's original central place in a decisive redrawing of the landscape. ${ }^{97}$ As discussed in the chapter on Theory (this volume), here is an instance where 'political change was closely related to the adoption of Christianity', or rather to the restructuring of the administrative landscape in a parochial context, involving 'an ideological rupture with the past' as more complex systems of governance were imposed on the island.

\section{Concluding remarks}

This chapter has argued that the circular forts on the coastal island of Walcheren should be understood as key elements in a landscape of negotiation, representing different political factions but drawing on a shared North Sea material culture repertoire in their attempts to establish power over the locality. This is a step removed from more traditional site-type approaches that regarded the ringwalburgen as a coherent group with a shared function, based on their common circular shape. Here, it is argued that different people can build similar things for different reasons, and that something that looks like a coherent group can in fact represent the outcome of a dialogue. Although the arguments presented here are necessarily preliminary, they allow for a more subtle appreciation of the complexities of the source material. The ringwalburgen did not have a single purpose or common origin, but were many things to different people all at once. They were defensive structures, attempts to establish different kinds of supralocal power over local communities, and statements of independence from other forms of authority. They were trading and manufacturing centres, and centres of political or religious importance. Their significance linked to different identities existing at different scales, and varied across time.

To return to the question of the interaction between the locality and the world beyond, it is clear that to consider either as a monolithic entity, or the relationship between the two as straightforwardly dichotomous, is overly simplistic. This was a period of considerable political turmoil; supralocal power was in constant flux as emperors, kings, Viking leaders and local magnates as well as bishops and monastic landholders competed and negotiated with each other, formed alliances or appointed deputies. I have argued that the construction, control, appropriation and abandonment of the ringwalburgen should be understood against this background. They represented key elements in the struggle for supralocal control over the island, and ultimately they allowed for the effective re-establishment of centralised royal control under Otto II.

Perhaps it is possible that I have overstated the effective agency of the actors involved, downplaying other external forces at work such as fluctuations in the dynamics of international long-distance trade networks, Viking piracy or environmental factors such as sea level change or coastal erosion. Of course, these were also factors contributing to the decline of Domburg and Souburg. But perhaps the political whims and power games of the Frankish kings and their associates and enemies have not received enough scholarly attention in this context so far. The discussion presented here is an invitation to debate, eventually hopefully resulting in a more nuanced appreciation of the active role of the various human actors involved.

\footnotetext{
95 See Semple, Perceptions of the Prehistoric, for the association between prehistoric monuments (such as burial mounds) and early medieval boundaries.

96 Henderikx, 'Walcheren van de 6e tot de 12e eeuw', pp. 141-46; Henderikx, 'Ontstaan en ruimtelijke ontwikkeling van Middelburg', p. 246. The church immediately outside the ringwalburg of Souburg visible on Fig. 2 was not founded until much later.

${ }^{97}$ Henderikx, 'Walcheren van de 6e tot de 12e eeuw', pp. 141-46; 'Ontstaan en ruimtelijke ontwikkeling van Middelburg', p. 246; Schoneveld, 'Historische Context', p. 36. The place-names can be understood as 'the east chapel' and 'the west chapel' respectively; Künzel, Blok, and Verhoeff, Lexicon.
} 
One aspect that has remained under-explored in this chapter is the neighbourhood, the rural and later urban population whose lives were ultimately affected by the comings and goings of different supralocal factions and the restructuring of the landscape in the eleventh century. This is partially due to an absence of evidence that inhibits close analysis of the everyday expressions of social behaviours (see the Introduction and Theory chapter, this volume). The surviving historical record is fragmentary at best, and not much concerned with issues of everyday life. What is more, as stated earlier on in this paper, archaeological evidence for rural settlement is only just emerging. Developer-funded archaeological excavation will undoubtedly continue to bring more evidence to light, allowing the debate to continue. One thing that is apparent at this stage, if only from the anecdote concerning the revolt against the Flemish nobility that this paper started with, is that the population of Walcheren did not let the various supralocal powers passively wash over them as they laid claim to (or lost interest in) the locality. That would be - as stated in the Introduction to this volume - to deny those at the lower social levels their full agency. Indeed, this effera gens was as easily controlled as the waves of the foaming sea.

\section{Acknowledgements}

The Society for Medieval Archaeology (Eric Fletcher Fund) and the Viking Society for Northern Research contributed to travel and accommodation costs to participate in the network's meetings in Akureyri (Iceland) and Stavanger (Norway) in 2012 and 2013. Many thanks must also go (in alphabetical order) to Pieterjan Deckers, Robert van Dierendonck, Malcolm Fraser, Peter Henderikx, Nelleke IJssennagger, Eduardo Manzano Moreno, Bernard Meijlink, Janet T. Nelson, Clifford Sofield and Chris Wickham for encouragement and useful feedback on various aspects of this paper, and of course to the other members of The Foundations of the European Space II network for an incredibly inspirational few years. Special thanks must go to the three editors of this volume, Julio Escalona, Orri Vésteinsson and Stuart Brookes. Their detailed written commentary on an earlier draft greatly improved the clarity of the argumentation. Responsibility for any remaining errors remains exclusively with the author.

\section{Figures}

Figure 1: Places mentioned in the text. Terrain model data from A. Jarvis, H. I. Reuter, A. Nelson, E. Guevara, 2008, Hole-filled seamless SRTM data V4, International Centre for Tropical Agriculture (CIAT), available from http://srtm.csi.cgiar.org. Sea data taken from GADM data, available from http://www.gadm.org. Reconstructed coastline redrawn from Bazelmans et al., Atlas van Nederland in bet Holoceen. Figure created by Chris Green and Letty ten Harkel, redrawn by ...

Figure 2: Aerial photograph of the ringwalburg of Souburg, shortly after the reconstruction of the rampart in 1994. The reconstructed entrance is visible on the western side. The - more recent house plots around the rampart are oriented towards the ringwalburg. Photo taken from the southwest. From the Collectie Zeeuws Archeologisch Depot (Collection of the Zeeland Archaeological Depot), copyright Stichting Cultureel Erfgoed Zeeland (SCEZ; Cultural Heritage Trust Zeeland), Middelburg. Reproduced with kind permission of SCEZ.

\section{Bibliography}

\section{Primary Sources}

Alcuin, Vita Sancti Willibrordi, ed. by Wilhelm Wattenbach and Ernst L. Dümmler, (Berlin: Weidmann, 1873)

Annales Bertiniani, ed. by Georg Waitz, (Hannover: Impensis Bibliopolii Hahniani, 1883)

Annales Fuldenses. ed. and trans. by Reinhold Rau, (Darmstadt: Wissenschaftliche Buchgesellschaft, 1975)

Annales Lindisfarnenses, ed. by Georg Heinrich Pertz, (Hannover: Hahnsche Buchhandlung, 1866)

Annals of St Bertin, trans. by Janet L. Nelson, (Manchester: Manchester University Press, 1991)

Asser, Life of Alfred. ed. and trans. by Simon D. Keynes and Michael Lapidge, (Harmondsworth: Penguin, 1983)

Baldrs Draumar. ed. and trans. by Ursula Dronke, (Oxford: Clarendon Press, 1997)

Dudo of St Quentin, History of the Normans. ed. and trans. by Eric Christiansen, (Woodbridge: The Boydell Press, 1998)

Gesta Episcoporum Virdunensium, ed. by Georg Waitz, (Hannover: Hahnsche Buchhandlung, 1841) 
Grógaldr, ed. by Friedrich Wilhelm Bergmann, trans. by Friedrich Wilhelm Bergmann, (Strassburg: Verlag von Karl J. Trübner, 1874)

Hallfreðr vandræðaskáld, Óláfsdrápa. ed. and trans. by Diana Whaley, (Turnhout: Brepols, 2013)

Historia de Sancto Cuthberto, ed. by Thomas Arnold, 2 vols, (London: Longman, 1882-85)

Lex Frisionum, ed. by Karl A. Eckhardt and Albrecht Eckhardt, (Hannover: Hahnsche Buchhandlung, 1982)

Miracula sancti Bertini Sithiensia: libellus miraculorum, ed. by Oswald Holder-Egger, (Hannover: Hahnsche Buchhandlung, 1887)

Odbert of St Bertin, Passio Friderici episcopi Traiectensis auctore Odberto, ed. by Oswald Holder-Egger, (Hannover: Hahn, 1887)

Sulpicius Severus, Dialogi, ed. by Jacques-Paul Migne, (Paris: Ecclesiasticae Ramos editore, 1845)

Sulpicius Severus, Vita Sancti Martini, ed. by Jacques Fontaine, (Paris: Èditions du Cerf, 1967)

Thiofrid of Echternach, Vita Willibrordi Metrica, ed. by Konrad Rossberg, (Leipzig: Lipsiae in Aedibus B. G. Teuneri, 1883)

\section{Secondary Works}

Andrén, Anders, Tracing Old Norse Cosmology: The World Tree, Middle Earth, and the Sun in Archaeological Perspectives (Lund: Nordic Academic Press, 2014)

Baker, John, and Stuart Brookes, eds, Beyond the Burghal Hidage: Anglo-Saxon Civil Defence in the Viking Age (Leiden: Brill, 2013)

Bazelmans, Jos and others, Atlas van Nederland in het Holoceen: landschap en bewoning vanaf de laatste ijstijd tot nu (Amsterdam: Uitgeverij Prometheus/Bert Bakker, 2011)

Besuijen, Guus, 'Rodanum: a study of the Roman settlement at Aardenburg and its metal finds' (unpublished MA Thesis thesis, Leiden University, 2008)

Blair, John, 'The British Culture of Anglo-Saxon England', in H. M. Chadwick Memorial Lectures, 24 (Cambridge: Cambridge: Department of Anglo-Saxon, Norse and Celtic, University of Cambridge, 2013)

Blair, John, The Foundations of Anglo-Saxon Society (in prep.)

Blok, Dirk P., 'De Franken in Nederland', in The Prehistory of the Netherlands, ed. by Leendert P. Louwe Kooijmans and others (Haarlem: Fibula-van Dishoeck, 1979)

Braat, Wouter C., 'Zeeland in the Vikingtijd', Archief: Mededelingen van het Koninklijk Zeeuws Genootschap der Wetenschappen (1954), 135-47

Burke, Peter J., and Jan E. Stets, 'Identity Theory and Social Identity Theory', Social Psychology Quarterly, 63 (2000), 224-37

Carver, Martin O. H., 'What were they thinking? Intellectual territories in Anglo-Saxon England', in The Oxford Handbook of Anglo-Saxon Archaeology, ed. by Helena Hamerow, David A. Hinton and Sally Crawford (Oxford: Oxford University Press, 2011), pp. 914-47

Cohen, Sidney L., Viking Fortresses of the Trelleborg Type (Copenhagen: Rosenkilde and Bagger, 1965)

Daleman, Margot, and Cuno G. Koopstra, 'Metaal en Slakmateriaal', in Een archeologische opgraving in de vroegmiddeleeuwse ringwalburg van Domburg, gem. Veere (Z.), ed. by Adrie Ufkes (Groningen: ARC, 2011), pp. 117-28, 207-34

Deckers, Pieterjan, 'Between Land and Sea: Landscape, Power and Identity in the Coastal Plain of Flanders, Zeeland and Northern France in the Early Middle Ages (AD 500-1000)' (unpublished unpublished doctoral thesis thesis, Vrije Universiteit Brussel, 2014)

Deckers, Pieterjan, and Letty Ten Harkel, eds, The Early Medieval Archaeology of the Island of Walcheren (in prep.)

Dijkstra, Juke, and Frieda S. Zuidhoff, eds, Kansen op de kwelder: archeologisch onderzoek op negen vindplaatsen in het nieuwe tracé van de Rijksweg N57 en de nieuwe rondweg ter boogte van Serooskerke (Walcheren), ADC Monografie, 10 (Amersfoort: ADC ArcheoProjecten, 2011)

Dijkstra, Menno, and Tim De Ridder, 'Circular Fortresses in the Provinces of North and South Holland', in Ringwälle und verwandte Strukturen des ersten Jahrtausends n. Chr. an Nord- und Ostsee, ed. by Martin Segschneider (Neumünster: Wachholtz Verlag, 2009), pp. 201-18

Dijkstra, Menno F. P., Rondom de mondingen van Rijn en Maas: landschap en bewoning tussen de 3 e en $9 e$ eeuw in ZuidHolland, in het bijzonder de Oude Rijnstreek (Leiden: Sidestone Press, 2011)

Dobat, Andres Siegfried, 'Die südskandinavischen Burgen vom Typ Trelleborg', in Ringwälle und verwandte Strukturen des ersten Jahrtausends n. Chr. an Nord- und Ostsee, ed. by Martin Segschneider (Neumünster: Wachholtz Verlag, 2009), pp. 51-70

Fallgren, Jan-Henrik, 'The Ölandic Ring-Forts and the Iron Age and Medieval Agricultural landscapes', in Ringwälle und verwandte Strukturen des ersten Jahrtausends $n$. Chr. an Nord- und Ostsee, ed. by Martin Segschneider (Neumünster: Wachholtz Verlag, 2009), pp. 27-49

Ferrell, Gillian, 'Space and Society: New Perspectives on the Iron Age of North-East England', in Different Iron Ages: studies on the Iron Age in Temperate Europe, ed. by J. D. Hill and Christopher G. Cumberpatch (Oxford: Archaeopress, 1995), pp. 129-47 
Grieve, Alexander, Willibrord: missionary in the Netherlands, 691-739 (Westminster: The Society for the Propagation of the Gospel in Foreign Parts, 1923)

Hamerow, Helena, Rural Settlements and Society in Anglo-Saxon England (Oxford: Oxford University Press, 2012)

Harrison, Stephen, 'Beyond longphuirt? Life and Death in Early Viking-Age Ireland', in Everyday Life in VikingAge Towns: Social Approaches to Towns in England and Ireland c. 800-1100, ed. by Dawn M. Hadley and Letty Ten Harkel (Oxford: Oxbow, 2013), pp. 61-72

Harsema, Otto, 'Farms Amongst Celtic Fields: Settlements on the Northern Fields', in The Prehistory of the Netherlands, ed. by Peter W. van den Broeke Leendert P. Louwe Kooijmans, Harry Fokkens and Annelou L. van Gijn (Amsterdam: Amsterdam University Press, 2005), pp. 543-55

Henderikx, Peter A., 'Walcheren van de 6e tot de 12e eeuw: nederzettingsgeschiedenis in fragmenten', Archief: Mededelingen van bet Koninklijk. Zeeuwsch Genootschap der Wetenschappen (1993), 113-56

Henderikx, Peter A., 'De ringwalburgen in het mondingsgebied van de Schelde in historisch perspectief', in Vroeg-middeleeunse ringwalburgen in Zeeland, ed. by Robert M. Van Heeringen, Peter A. Henderikx and Alexandra Mars (Goes: De Koperen Tuin, 1995), pp. 71-112

Henderikx, Peter A., 'Ontstaan en ruimtelijke ontwikkeling van Middelburg (9e-14e eeuw)', in Middeleeunse toestanden: archeologie, geschiedenis en monumentenzorg, aangeboden aan Herbert Sarfatij bij zijn 65e verjaardag, ed. by Philippus J. Woltering, Willem J. H. Verwers and G. H. Scheepstra (Amersfoort/Hilversum: Verloren, 2002), pp. 241-66

Henderikx, Peter A., 'Graaf en stad in Holland en Zeeland in de twaalfde en vroege dertiende eeuw', in Stadswording in de Nederlanden: op zoek naar overzicht, ed. by Reinout Rutte and Hildo Van Engen (Hilversum: Verloren, 2005), pp. 47-62

Henderikx, Peter A., 'De vroegste geschiedenis en de ruimtelijke ontwikkeling van Middelburg in de Middeleeuwen en Nieuwe Tijd, met name van de omgeving van de Noordmonster- of SintPieterskerk', in Middelburg - Berghuijskazerne, ed. by Sebastiaan Ostkamp, Juke Dijkstra and G. Williams (Amersfoort: ADC ArcheoProjecten, 2006), pp. 13-21

Henderikx, Peter A., 'Walcheren in de vroege middeleeuwen: eiland, koningsgoed en handelsnederzetting (preliminary title)', in The Early Medieval Archaeology of the Island of Walcheren, ed. by Pieterjan Deckers and Letty Ten Harkel (in prep.)

Henning, Joachim, 'Civilization versus barbarians? Fortification techniques and politics in the Carolingian and Ottonian borderlands', in Borders, Barriers, and Ethnogenesis: Frontiers in Late Antiquity and the Middle Ages, ed. by Florin Curta (Turnhout: Brepols, 2005), pp. 23-34

Hill, David, 'Appendix 3: A Short Gazetteer of Postulated Continental Wics', in Wics: The Early Medieval Trading Centres of Northern Europe, ed. by David Hill and Robert Cowie (Sheffield: Sheffield Academic Press, 2001), pp. 104-10

Hill, David, and Alexander R. Rumble, The Defence of Wessex. The Burghal Hidage and Anglo-Saxon Fortifications (Manchester - New York: Manchester University Press, 1996)

Huizinga, Johan, 'Burg en kerspel in Walcheren', Mededeelingen der Koninklijke Academie van Wetenschappen, Afdeeling Letterkunde, 80 (B: 2) (1935), 27-62

IJssennagger, Nelleke L., 'Between Frankish and Viking: Frisia and Frisians in the Viking Age', Viking and Medieval Scandinavia, 9 (2013), 69-89

Kars, Henk, 'De voorwerpen van natuursteen', in V roeg-middeleeuwse ringwalburgen in Zeeland, ed. by Robert M. Van Heeringen, Peter A. Henderikx and Alexandra Mars (Goes: De Koperen Tuin, 1995), pp. 18491

Künzel, R. E., Dirk P. Blok, and J. M. Verhoeff, Lexicon van Nederlandse Toponiemen tot 1200 (Amsterdam: P. J. Meertensinstituut voor Dialectologie, Volkskunde en Naamkunde, 1988)

Lauwerier, Roel C. G. M., 'Veeteelt in Oost-Souburg', in Vroeg-middeleenwse ringwalburgen in Zeeland, ed. by Robert M. Van Heeringen, Peter A. Henderikx and Alexandra Mars (Goes: De Koperen Tuin, 1995), pp. 213-18

Lauwerier, Roel C. G. M., and Robert M. Van Heeringen, 'Objects of Bone, Antler and Horn from the Circular Fortress of Oost-Souburg, the Netherlands (AD 900-975)', Medieval Archaeology, 39 (1995), $71-90$

Lauwerier, Roel C. G. M., and H. W. Van Klaveren, 'Bewerkt bot', in V roeg-middeleeuwse ringwalburgen in Zeeland, ed. by Robert M. Van Heeringen, Peter A. Henderikx and Alexandra Mars (Goes: De Koperen Tuin, 1995), pp. 193-212

Lebecq, Stéphane, Marchands et Navigateurs Frisons du Haut Moyen Áge, 2 vols (Lille: Presses universitaires de Lille, 1983)

Lebecq, Stéphane, 'L'Emporium Proto-Médiéval de Walcheren-Domburg: Une mise en perspective', in Peasants \& Townsmen in Medieval Europe: Studia in Honorem Adriaan Verbulst, ed. by J. M. Duvosquel and Erik Thoen (Ghent: Snoeck-Ducaju \& Zoon, 1995), pp. 73-89

Loveluck, Christopher P., and Dries Tys, 'Coastal Societies, Exchange and Identity along the Channel and Southern North Sea Shores of Europe, AD 600-1000', Journal of Maritime Archaeology, 1 (2006), 14069 
Meijlink, Bernard, 'New reflections on the Walcheren ringfortresses based on recent results of excavations in Domburg and Middelburg', in The Early Medieval Archaeology of the Island of Walcheren, ed. by Pieterjan Deckers and Letty Ten Harkel (in prep.)

Meijlink, Bernard, and Bram Silkens, Middeleeunse bewoning bij de Duinburg: een archeologische opgraving aan de Roosjesweg (plangebied De Golfslag) te Domburg, Gemeente Veere, Walcherse Archeologische Rapporten, 11 (Domburg: Walcherse Archeologische Dienst, 2012)

Olivier, Laurent, The Dark Abyss of Time: Archaeology and Memory (Plymouth: Alta Mira, 2011)

Oswald, Alastair, 'An Iron Age Hillfort on Fawcet Shank: Survey Report', (Swindon: English Heritage, 2000)

Pohl, Walter, 'Conclusion: the transformation of frontiers', in The Transformation of Frontiers from Late Antiquity to the Carolingians, ed. by Walter Pohl, Ian Wood and Helmut Reimitz (Leiden: Brill, 2001), pp. 24760

Pohl, Walter, 'Staat und Herrschaft im Frühmittelalter: Überlegungen zum Forschungsstand', in Staat im frühen Mittelalter, ed. by Stuart Airlie, Walter Pohl and Helmut Reimitz (Wien: Österreischische Akademie der Wissenschaften, 2004), pp. 9-38

Price, Neil, The Viking Way: Religion and War in Late Iron Age Scandinavia (Uppsala: Uppsala University, 2002)

Roesdahl, Else, Fyrkat: en jysk vikingeborg. Vol 2: Oldsagerne og gravpladsen (Copenhagen: I commission hos herm. H. J. Lynge og søn, 1977)

Roesdahl, Else, and Søren M. Sindbæk, 'Introduction', in Aggersborg: The Viking-Age Settlement and Fortress, ed. by Else Roesdahl and others (Moesgaard: Jutland Archaeological Society, 2014), pp. 11-16

Roesdahl, Else, and Søren M. Sindbæk, 'The Purpose of the Fortress', in Aggersborg: The Viking-Age Settlement and Fortress, ed. by Else Roesdahl and others (Moesgaard: Jutland Archaeological Society, 2014), pp. 383-414

Roesdahl, Else and others, eds, Aggersborg: The Viking-Age Settlement and Fortress (Moesgaard: Jutland Archaeological Society, 2014)

Roymans, Nico, Tribal Societies in Northern Gaul: An Anthropological Perspective (Amsterdam: Albert Egges van Giffen Instituut voor Prae- en Protohistorie, 1990)

Sawyer, Peter, Kings and Vikings: Scandinavia and Europe, AD 700-1100 (London: Methuen, 1982)

Schinkel, Kees, 'Hamlets on the Move: Settlements in the Southern and Central Parts of the Netherlands', in The Prehistory of the Netherlands, ed. by Peter W. van den Broeke Leendert P. Louwe Kooijmans, Harry Fokkens and Annelou L. van Gijn (Amsterdam: Amsterdam University Press, 2005), pp. 519-41

Schoneveld, Jan, 'Historische Context', in Een archeologische opgraving in de vroegmiddeleeunse ringwalburg van Domburg, gem. Veere (Z.), ed. by Adrie Ufkes (Groningen: ARC, 2011), pp. 33-36

Segschneider, Martin, 'Die Ringwälle auf den nordfriesischen Inseln', in Ringwälle und verwandte Strukturen des ersten Jahrtausends n. Chr. an Nord- und Ostsee, ed. by Martin Segschneider (Neumünster: Wachholtz Verlag, 2009), pp. 99-111

Semple, Sarah, Perceptions of the Prehistoric in Anglo-Saxon England: Religion, Ritual and Rulership (Oxford: Oxford University Press, 2013)

Sofield, Clifford, 'Living with the Dead: Human Burials in Anglo-Saxon Settlement Contexts', The Archaeological Journal (forthcoming)

Stancliffe, Clare, St. Martin and his Hagiographer: History and Miracle in Sulpicius Severus (Oxford: Clarendon Press, 1983)

Stuart, Petrus, and Julianus E. Bogaers, Nehalennia: Römische Steindenkmäler aus der Oosterschelde bei Colijnsplaat, Collections of the National Museum of Antiquities at Leiden, 11 (Leiden: Rijksmuseum van Oudheden, 2001)

Ten Harkel, Letty, 'A Viking Age Landscape of Defence in the Netherlands? The Late Ninth- and TenthCentury Ringwalburgen in the Dutch Province of Zeeland', in Landscapes of Defence in the Viking Age, ed. by John Baker, Stuart Brookes and Andrew Reynolds (Turnhout: Brepols, 2013), pp. 223-59

Trimpe Burger, Jan A., 'Oost-Souburg, Province of Zeeland: A Preliminary Report on the Excavation of the Site of an Ancient Fortress (1969-1971)', Berichten van de Rijksdienst voor het Oudheidkundig Bodemonderzoek, 23 (1973), 355-65

Trimpe Burger, Jan A., 'Aardenburg - Rodanburg - Burg aan de Rudannâ', Naamkunde, 17 (1985), 335-46

Tuinman, Niels, 'Romeinse Nehalennia-altaren in Zeeland: locale fabricaten of geïmporteerde producten?' (unpublished doctoral thesis thesis, University of Leiden, 2012)

Ufkes, Adrie, Een archeologisch onderzoek in de vroegmiddeleeunse ringwalburg op het Abdijplein te Middelburg, gemeente Middelburg (Z.), 119 (Groningen: ARC, 2006)

Ufkes, Adrie, 'Conclusie', in Een archeologische opgraving in de vroegmiddeleeunse ringwalburg van Domburg, gem. Veere (Z.), ed. by Adrie Ufkes (Groningen: ARC, 2011), pp. 185-90

Ufkes, Adrie, Een archeologische opgraving in de vroegmiddeleeuwse ringwalburg van Domburg, gem. Veere (Z.), 223 (Groningen: ARC, 2011)

Ufkes, Adrie, 'Sporen en structuren', in Een archeologische opgraving in de vroegmiddeleeunse ringwalburg van Domburg, gem. Veere (Z.), ed. by Adrie Ufkes (Groningen: ARC, 2011), pp. 37-108 
Van Dierendonck, Robert M., 'The Early Medieval Circular Fortresses in the Province of Zeeland, The Netherlands: Ten Years After', in Ringwälle und verwandte Strukturen des ersten Jahrtausends n. Chr. an Nord- und Ostsee, ed. by Martin Segschneider (Neumünster: Wachholtz Verlag, 2009), pp. 249-74

Van Dierendonck, Robert M., 'Romeinse tijd', in Geschiedenis van Zeeland, vol. 1: Prehistorie-1550, ed. by Paul Brusse and Peter A. Henderikx (Zwolle: WBooks, 2012), pp. 42-55

Van Dierendonck, Robert M. van, and Wouter K. Vos, De Romeinse agglomeratie Aardenburg: onderzoek naar de ontwikekeling, structuur en datering van de Romeinse castella en bun omgeving, opgegraven in de periode 1955-beden (Middelburg: Hazenberg Archeologie, 2013)

Van Heeringen, Robert M., 'Archeologische kroniek van Zeeland over 1992', Archief: Mededelingen van het Koninklijk. Zeeuwsch Genootschap der Wetenschappen (1993), 187-203

Van Heeringen, Robert M., 'Archeologische kroniek van Zeeland over 1993', Archief: Mededelingen van het Koninklijk Zeeunsch Genootschap der Wetenschappen (1994), 230-42

Van Heeringen, Robert M., 'De grondsporen', in Vroeg-middeleeuwse ringwalburgen in Zeeland, ed. by Robert M. Van Heeringen, Peter A. Henderikx and Alexandra Mars (Goes: De Koperen Tuin, 1995), pp. 11543

Van Heeringen, Robert M., 'De resultaten van het archeologisch onderzoek van de Zeeuwse ringwalburgen', in V roeg-middeleeuwse ringwalburgen in Zeeland, ed. by Robert M. Van Heeringen, Peter A. Henderikx and Alexandra Mars (Goes: De Koperen Tuin, 1995), pp. 17-39

Van Heeringen, Robert M., 'Glas en metaal', in V roeg-middeleeuwse ringwalburgen in Zeeland, ed. by Robert M. Van Heeringen, Peter A. Henderikx and Alexandra Mars (Goes: De Koperen Tuin, 1995), pp. 17183

Van Heeringen, Robert M., 'Inleiding: De burgterreinen in hun huidige gedaante', in Vroeg-middeleeunse ringwalburgen in Zeeland, ed. by Robert M. Van Heeringen, Peter A. Henderikx and Alexandra Mars (Goes: De Koperen Tuin, 1995), pp. 15

Van Heeringen, Robert M., 'Kolonisatie en bewoning in het mondingsgebied van de Schelde in de vroege middeleeuwen vanuit archeologisch perspectief', in Vroeg-middeleeunse ringwalburgen in Zeeland, ed. by Robert M. Van Heeringen, Peter A. Henderikx and Alexandra Mars (Goes: De Koperen Tuin, 1995), pp. 40-70

Van Heeringen, Robert M., 'The Construction of Frankish Circular Fortresses in the Province of Zeeland (SW Netherlands) in the End of the Ninth Century', Chateau Gaillard, 18 (1998), 241-49

Van Heeringen, Robert M., 'On Unsteady Ground: Settlements in the Western Netherlands', in The Prehistory of the Netherlands, ed. by Leendert P. Louwe Kooijmans and others (Amsterdam: Amsterdam University Press, 2005), pp. 581-95

Van Heeringen, Robert M., Peter A. Henderikx, and Alexandra Mars, eds, Vroeg-middeleeuwse ringwalburgen in Zeeland (Goes: De Koperen Tuin, 1995)

Van Heeringen, Robert M., and Frans Verhaeghe, 'Het aardewerk', in Vroeg-middeleeunse ringwalburgen in Zeeland, ed. by Robert M. Van Heeringen, Peter A. Henderikx and Alexandra Mars (Goes: De Koperen Tuin, 1995), pp. 145-70

Veeckman, Johan, 'The Semi-Circular Fortified Medieval Settlement of Antwerp, Belgium', in Ringwälle und verwandte Strukturen des ersten Jahrtausends n. Chr. an Nord- und Ostsee, ed. by Martin Segschneider (Neumünster: Wachholtz Verlag, 2009), pp. 275-84

Verhulst, Adriaan, The Rise of Cities in North-West Europe (Cambridge: Cambridge University Press, 1999)

Waterbolk, H. T., 'Walled Enclosures of the Iron Age in the North of the Netherlands', Palaeohistoria, 19 (1977), 97-172

Werveke, Hans van, 'De oudste burchten aan de Vlaamse en de Zeeuwse kust', Mededelingen van de Koninklijke Vlaamse Academie voor Wetenschappen, Letteren en Schone Kunsten van Belgïe, Klasse der Letteren, 27 (1965), 322

Whaley, Diana, Poetry from the Kings' Sagas, 1. From Mythical Times to c. 1035, 2 vols, Vol. 1 (Turnhout: Brepols, 2012)

Wood, Susan, The Proprietary Church in the Medieval West (Oxford: Oxford University Press, 2006)

Wullink, Aard-Jan, 'Fysische Geografie', in Een archeologische opgraving in de vroegmiddeleeuwse ringwalburg van Domburg, gem. Veere (Z.), ed. by Adrie Ufkes (Groningen: ARC, 2011), pp. 27-32 